\title{
An Update on the Effectiveness of Probiotics in the Prevention and Treatment of Cancer
}

\author{
Vidya Sankarapandian ${ }^{1}$, Balu Alagar Venmathi Maran ${ }^{2}$ (D), Ramya Lakshmi Rajendran ${ }^{3}$, Manasi P. Jogalekar ${ }^{4}$, \\ Sridharan Gurunagarajan ${ }^{5}$ D , Rajapandiyan Krishnamoorthy ${ }^{6}$, Prakash Gangadaran $3,7, *$ (D) \\ and Byeong-Cheol Ahn $3,7, *$ (D)
}

1 Department of Microbiology, Srimad Andavan Arts and Science College, Bharathidasan University, Trichy 620005, India; sne777@andavancollege.ac.in

2 Borneo Marine Research Institute, Universiti Malaysia Sabah, Kota Kinabalu 88400, Malaysia; bavmaran@ums.edu.my

3 Department of Nuclear Medicine, School of Medicine, Kyungpook National University, Daegu 41944, Korea; ramyag@knu.ac.kr

4 Helen Diller Family Comprehensive Cancer Center, University of California San Francisco, San Francisco, CA 94158, USA; manasi.jogalekar@ucsf.edu

5 Department of Biochemistry, Srimad Andavan Arts and Science College, Bharathidasan University, Trichy 620005, India; srig@andavancollege.ac.in

6 Nanobiotechnology and Molecular Biology Research Lab, Department of Food Science and Nutrition, College of Food and Agriculture Sciences, King Saud University, Riyadh 4545, Saudi Arabia; rkrishnamoorthy@ksu.edu.sa

7 BK21 FOUR KNU Convergence Educational Program of Biomedical Sciences for Creative Future Talents, Department of Biomedical Science, School of Medicine, Kyungpook National University, Daegu 41944, Korea

* Correspondence: prakashg@knu.ac.kr (P.G.); abc2000@knu.ac.kr (B.-C.A.); Tel.: +82-53-420-4914 (P.G.); +82-53-420-5572 (B.-C.A.); Fax: +82-53-200-6447 (B.-C.A.)

Citation: Sankarapandian, V.; Venmathi Maran, B.A.; Rajendran, R.L.; Jogalekar, M.P.; Gurunagarajan, S.; Krishnamoorthy, R.; Gangadaran, P.; Ahn, B.-C. An Update on the Effectiveness of Probiotics in the Prevention and Treatment of Cancer. Life 2022, 12, 59. https:/ / doi.org/ 10.3390/life12010059

Academic Editor: Marisa Colone

Received: 22 December 2021

Accepted: 29 December 2021

Published: 2 January 2022

Publisher's Note: MDPI stays neutral with regard to jurisdictional claims in published maps and institutional affiliations.

Copyright: (C) 2022 by the authors. Licensee MDPI, Basel, Switzerland. This article is an open access article distributed under the terms and conditions of the Creative Commons Attribution (CC BY) license (https:// creativecommons.org/licenses/by/ $4.0 /)$.

\begin{abstract}
Probiotics are living microbes that play a significant role in protecting the host in various ways. Gut microbiota is one of the key players in maintaining homeostasis. Cancer is considered one of the most significant causes of death worldwide. Although cancer treatment has received much attention in recent years, the number of people suffering from neoplastic syndrome continues to increase. Despite notable improvements in the field of cancer therapy, tackling cancer has been challenging due to the multiple properties of cancer cells and their ability to evade the immune system. Probiotics alter the immunological and cellular responses by enhancing the epithelial barrier and stimulating the production of anti-inflammatory, antioxidant, and anticarcinogenic compounds, thereby reducing cancer burden and growth. The present review focuses on the various mechanisms underlying the role of probiotics in the prevention and treatment of cancer.
\end{abstract}

Keywords: probiotics; immunomodulation; metastasis; biotherapy; oncogene kinase

\section{Introduction}

The term "probiotics" has a Greek origin and it literally means "for Life" [1]. The term was coined by Lilley and Stillwell in 1965 [2]. Fermented products, such as cheese, bread, wine, beer, and kefir, were widely used for their nutritional and therapeutic benefits long before the identification of probiotics [3]. Elie Metchnikoff, a Nobel laureate, was the first scientist to describe probiotics. He hypothesized that manipulating the intestinal microbiome with host-friendly bacteria would confer health benefits and delay senility [4] He also considered Lactobacillus as a probiotic [1]. Hence, the credit of pioneering probiotics research is eternally devoted to Elie Metchnikoff. The Food and Agricultural Organization (FAO) defines probiotics as "live microorganisms which, when consumed in adequate amounts, confer beneficial health effects on the host" [5]. The human gastrointestinal tract is a reservoir of a complex and dynamic population of microorganisms (the gut microbiota), which mainly comprises bacteria (in number over 1014) and exerts a significant influence on 
the host during homeostasis and disease. The presence of such an abundance of intestinal bacteria contributes to the human body, having approximately ten times more prokaryotic cells than eukaryotic cells [6]. In recent years, studies on the use of probiotics for the prevention and treatment of human diseases have gained momentum [7].

\subsection{Characteristics of Probiotics}

Several researchers have documented the characteristics microorganisms should have to be effective probiotics (Figure 1). Briefly, probiotics:

$\checkmark$ Are non-pathogenic [8];

$\checkmark \quad$ Can survive passage through the digestive system [9];

$\checkmark \quad$ Can tolerate bile salts [10];

$\checkmark \quad$ Are able to colonize the intestinal epithelium [11];

$\checkmark$ Can maintain a mutualistic association with the host [12];

$\checkmark$ Possess positive immunomodulatory effects [13];

$\checkmark \quad$ Are genetically safe [5];

$\checkmark \quad$ Produce beneficial metabolites such as organic acids, bacteriocin, and hydrogen peroxide [14].

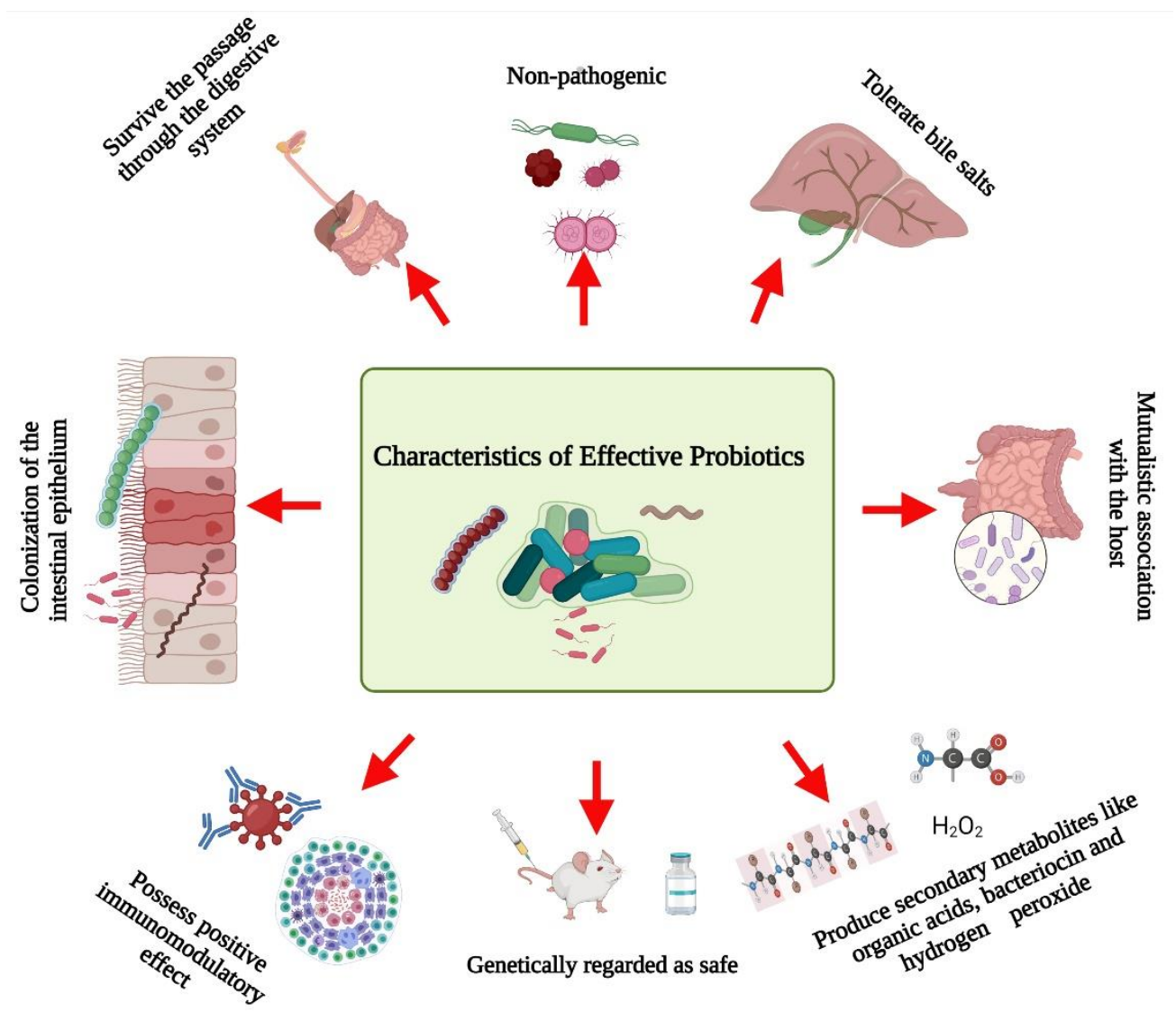

Figure 1. Schematic representation of the characteristics of effective probiotics. Created with BioRender.com, accessed on 28 December 2021.

\subsection{Sources and Types of Probiotics}

Several kinds of probiotics have been identified from different sources during the past decade. According to Śliżewska et al. [6], an organism identified as a probiotic usually belongs to the genera of bacteria or fungi, including Lactobacillus, Pediococcus, Propionibacterium, Leuconostoc, Streptococcus, Enterococcus, Bifidobacterium, Bacillus, Saccharomyces cerevisiae, Candida pintolopesii, Aspergillus oryzae, and Aspergillus niger. Lactic acid bacteria (LAB) are one of the most widely used probiotics [15]. Among LAB, Bifidobacterium and 
Lactobacillus are the most important microbes [16]. These probiotic microorganisms are isolated from different sources [6], such as vegetables, beef, salted crab, seafood, soybeans, yogurt, cheese, milk, kefir, human breast milk, barley, oat groats, molasses, grains, marine fish, smoked salmon, cabbage, wheat flour, sourdough, dairy products, chicken crop, porcine, and mangroves.

\section{Probiotics and Cancer}

Probiotics are used to treat several health conditions, such as dermatitis, inflammation, halitosis, diarrhoea, irritable bowel syndrome, hypercholesterolemia, obesity, urogenital infections, and cancers [17]. In particular, probiotics have gained attention due to their ability to modulate cancer signalling (Figure 2) [18]. Notably, probiotics can modulate cancers via the (a) induction of apoptosis [19], (b) inhibition of mutagenic activity [20], (c) downregulation of oncogene expression [21], (d) induction of autophagy [22,23], (e) inhibition of kinases [24], (f) reactivation of tumour suppressors [25], and (g) prevention of metastasis [26]. The anticancer properties of probiotics are mainly attributed to metabiotics (Figure 3). The term "metabiotics" refers to the structural components of probiotic microorganisms, their metabolites, and signalling molecules having a defined chemical structure that can optimize host-specific physiological functions as well as regulatory, metabolic, and behaviour reactions associated with the activity of the host [27].

\section{Mechanism underlying prevention}

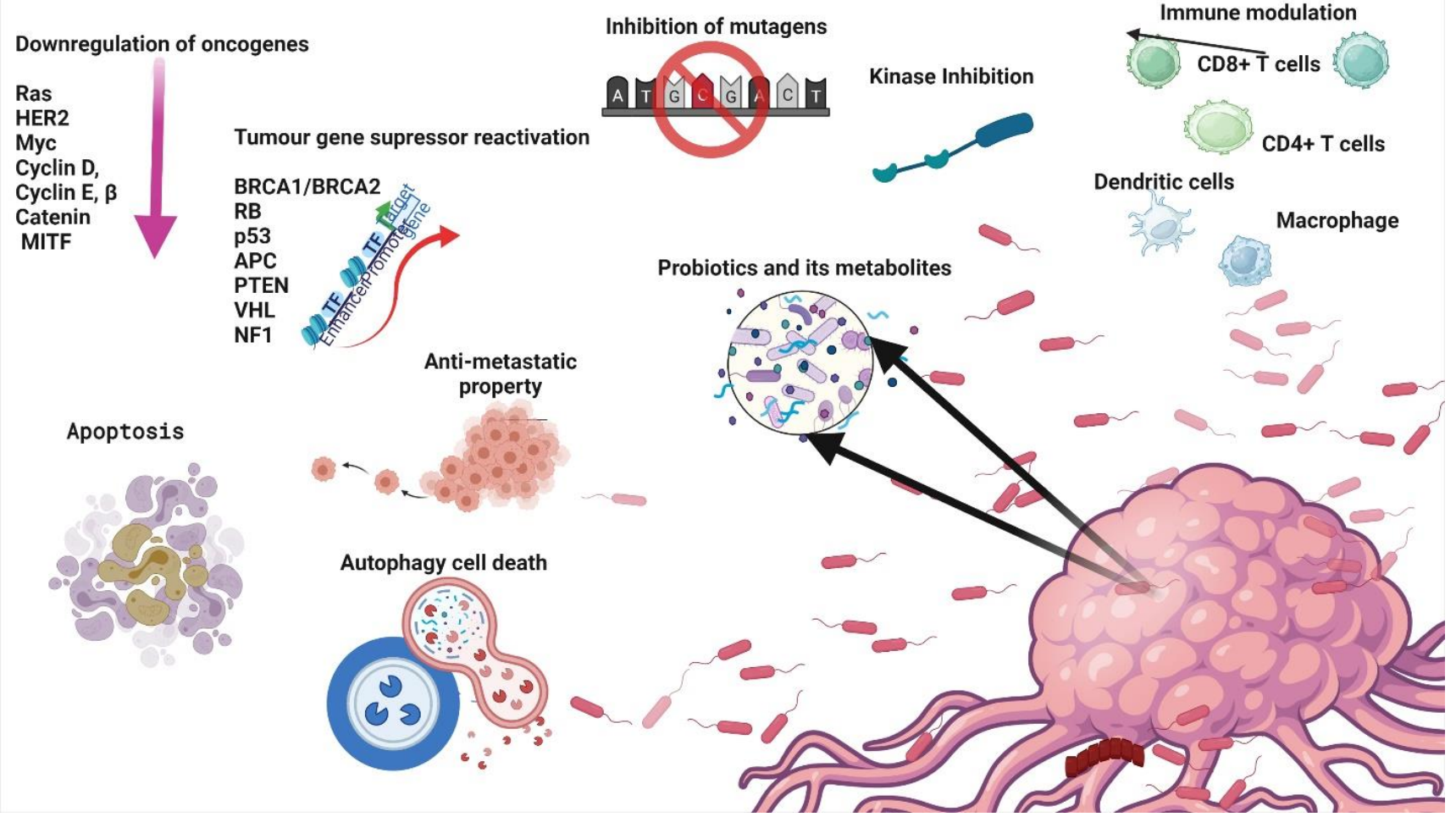

Figure 2. Schematic representation of mechanisms underlying the prevention or treatment of cancer using probiotics. The strategies include apoptosis, antimutagenic activity, down regulation of oncogene expression, autophagy induction in tumor cells, kinase inhibition, immune modulation, tumour gene suppressor reactivation, and antimetastatic property. Created with BioRender.com, accessed on 28 December 2021. 


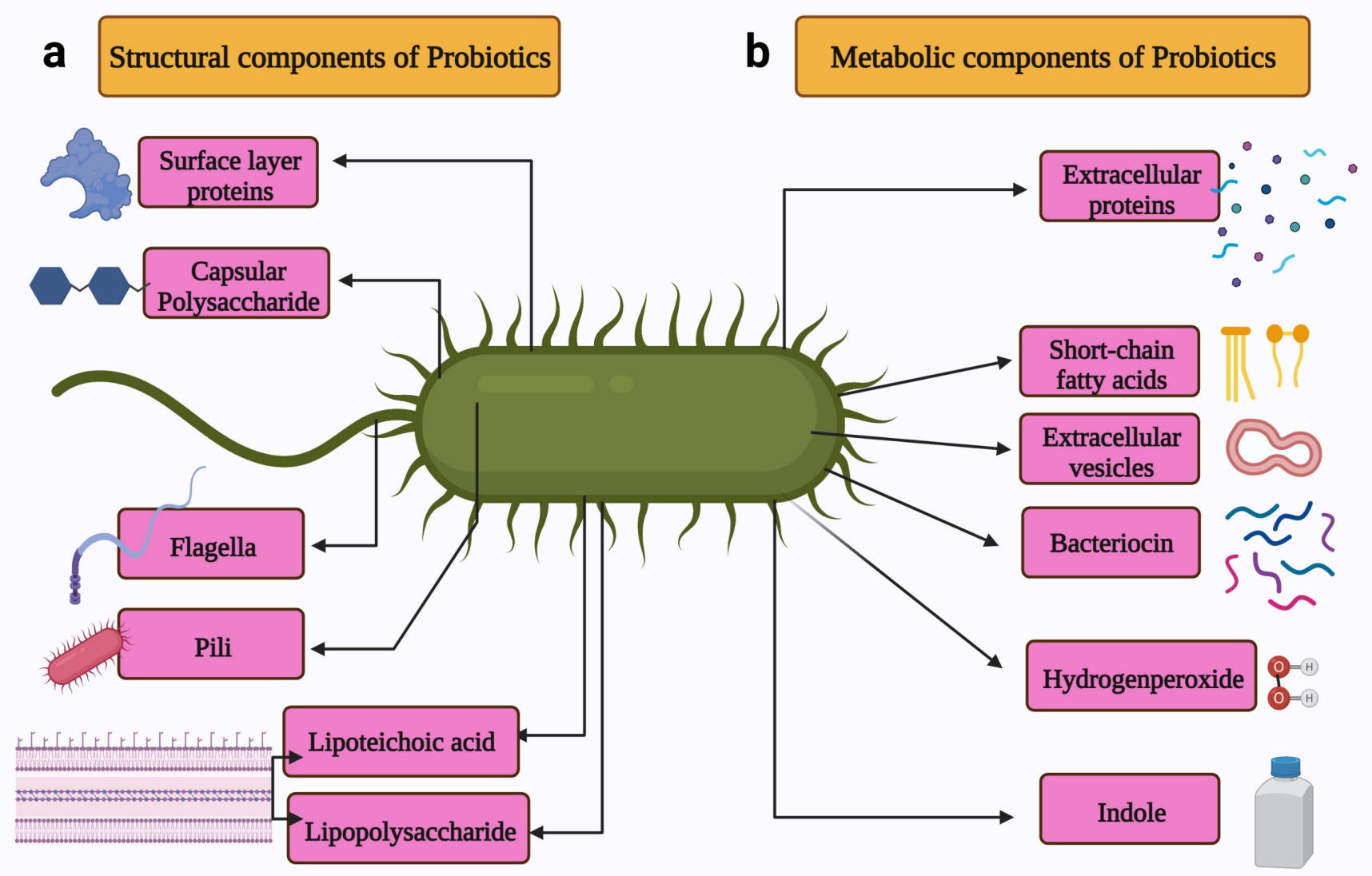

Figure 3. Schematic representation of the metabiotics of probiotics. The metabiotics of probiotics can be divided in two types: (a) Structural components include surface proteins, capsular polysaccharide, flagella, pili, lipoteichoic acid, and lipopolysaccharide. (b) Metabolic components include extracellular proteins, short-chain fatty acids, extracellular vesicles, bacteriocin, and indole. Created with BioRender.com, accessed on 28 December 2021.

The structural components of probiotics include surface layer proteins, capsular polysaccharides, flagella, pili, lipoteichoic acid, and lipopolysaccharides. These structural components constitute microbe-associated molecular patterns [28]. The metabolites produced by the probiotics include secreted proteins (extracellular proteins), hydrogen peroxide, indole, extracellular vesicles, short-chain fatty acids, and bacteriocins [29].

\section{Role of Probiotics in Apoptosis Induction}

Several reports suggest that probiotics inhibit tumorigenesis and cancer progression via apoptosis, but only a few studies have deduced the exact mechanism underlying apoptosis induction. According to Pfeiffer and Singh (2018), apoptosis is a promising target for cancer therapy [30]. Apoptosis is a form of cell death in which a "suicide" program is triggered, leading to DNA fragmentation, cytoplasm reduction, membrane changes, and cell death without lysis or damaging neighbouring cells [31]. The inhibition of tumour growth is one of the main functions of apoptosis [32]. Three interconnected pathways - mitochondrial/intrinsic pathway, death receptor/extrinsic pathway, and perforin/granzyme pathway-are involved in apoptosis [33]. The genes involved in apoptosis are tumour necrosis factor (TNF), inhibitors of apoptosis proteins, caspases, B cell lymphoma (Bcl)-2, and p53 gene [34]. Several reports indicate that probiotics induce apoptosis in cancer cells by modulating Bax/Bcl-2 and caspases $[35,36]$ (Figure 4). In addition, colicin, a bacteriocin isolated from Escherichia coli, was found to have anticancer activity, 
resulting in the formation of minute pores on the plasma membrane [37]. These pores induce apoptosis and cause cell cycle arrest in the G1 phase. Preet et al. demonstrated the synergistic effect of nisin in combination with doxorubicin. They found that nisin and doxorubicin reduce the tumour volume by $66.82 \%$ in mice when compared with the untreated control [38]. Konishi et al. [39] analysed the probiotic-derived tumour-suppressive molecule ferrochrome, which has the ability to inhibit colon cancer progression via c-jun $\mathrm{N}$-terminal kinase (JNK)-mediated apoptosis. Moreover, conjugated linoleic acid, a functional lipid produced by Lactobacillus plantarum (LPCLA), mediated apoptosis in breast cancer cells via the downregulation of the NFKB pathway [40]. Lactobacillus acidophilus and Bifidobacterium bifidum showed increased cytotoxic effects against breast and colon cancer cell lines by upregulating Bax, IFN- $\gamma$, and TNF- $\alpha$ expression and downregulating $\mathrm{Bcl} 2$ expression [41]. Further L. acidophilus induces apoptosis by increasing the mRNA expression of survivin and decreasing the mRNA expression of SMAC [42]. Lactobacillus casei significantly increases the expression of the hBD-2 gene in the cancer colon cell line HT29 [43]. Joo et al. reported that nisin induced apoptosis and reduced proliferation in HNSCC cells by increasing intracellular calcium, inducing cell cycle arrest, and activating cation transport regulator homolog 1 (Chac1) [44]. Jan et al. found that mitochondrial pore formation pathways induce apoptosis through caspase activation. Additionally, a study revealed that Propionibacterium caused apoptosis in colorectal carcinoma cells via the action of short-chain fatty acids on the mitochondria [45]. Overall, researchers continue to explore the apoptotic potential of probiotics on cancers. The field of probiotics-induced apoptosis research is rapidly progressing. Although many apoptotic proteins have been discovered, their molecular mechanisms of action largely remain unknown.

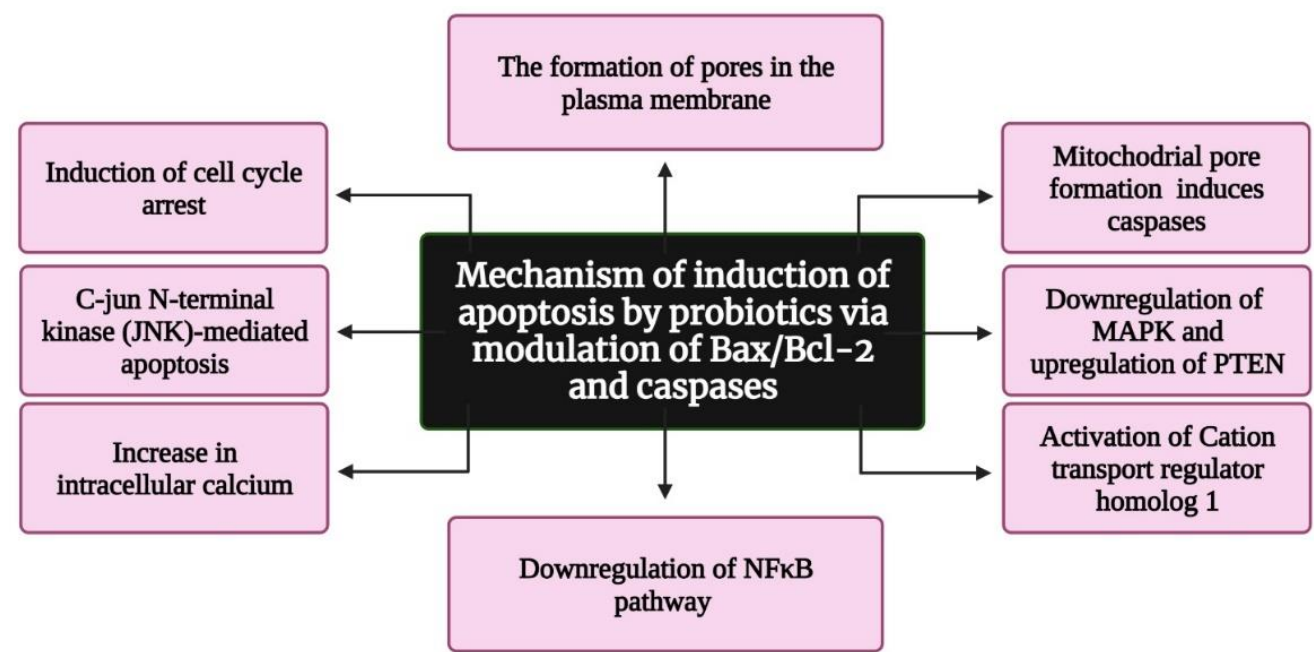

Figure 4. Flowchart representing the mechanism of apoptosis induction by probiotics via the modulation of Bax/Bcl-2 and caspases. Bax: Bcl-2-associated X protein; Bcl-2: B cell lymphoma 2; MAPK: mitogen-activated protein kinase; PTEN: Phosphatase and TENsin homolog deleted on chromosome 10; and NFkB: nuclear factor kappa-light-chain-enhancer of activated B cells. Created with BioRender.com, accessed on 28 December 2021.

Asoudeh-Fard et al. found that the probiotic L. plantarum induces apoptosis via the downregulation of mitogen-activated protein kinases (MAPK) and the upregulation of phosphatase and tensin homolog (PTEN) pathways [46]. Additionally, Zhang et al. reported that metabolites of Lactobacillus spp. have a negative effect on the viability of CAL27 (human tongue squamous cell carcinoma) cells and induce apoptosis [47]. L. salivarius was found to reduce oral cancer in rats via the downregulation of COX-2/PCNA expression and the induction of apoptosis [48]. As the alteration in normal oral flora promotes oral cancer [49], the normal flora, particularly probiotics, plays a crucial role in the prevention of oral cancer [50]. 


\section{Probiotics and Autophagy}

Autophagy is a self-degradation process in which double-membrane autophagosomes sequester organelles or portions of the cytosol fuse with lysosomes for breakdown by resident hydrolases [51]. Although autophagy is essential for maintaining homeostasis in normal cells, it has also been implicated in various diseases. Increasing evidence suggests that autophagy promotes both tumour suppression [52] and progression [53]. Autophagy is vital for the elimination of damaged cells or aged proteins and organelles. Additionally, autophagy defects may lead to DNA damage and cancer, suggesting their role in tumour suppression [54]. Literature on the inhibition of tumour growth using probiotics via autophagy induction is lacking. Wang et al. reported that a surface protein from L. acidophilus induced HCT116 cell death by altering the levels of an autophagy-linked protein-microtubule-associated protein 1 light chain 3 (Figure 5) [55]. In addition, LAB promoted apoptosis induction in the presence of 5-fluorouracil by triggering Beclin1/GRP78mediated autophagy activation [6]. The cell-bound exopolysaccharide of probiotics can potentially activate autophagy in colon cancer cells by stimulating Beclin1/GRP78 and the core regulators of intrinsic apoptosis pathway-Bcl-2 and Bak proteins [22]. The sequence of steps involved in autophagy are (a) sequestration (b) transport to lysosomes, (c) degradation, and (d) utilization of degradation products [56]. The important genes and proteins involved in autophagy include Beclin-1, lysosome-associated membrane protein, damage-regulated autophagy modulator 1, and p53 [57]. There are four different types of autophagy: chaperone-mediated autophagy, selective autophagy, macroautophagy, and microautophagy [58]. Autophagy can either promote or inhibit tumour development depending on several factors, such as cancer type or age [57]. However, probiotics-mediated autophagy and its role in the elimination of cancer warrants further investigation.

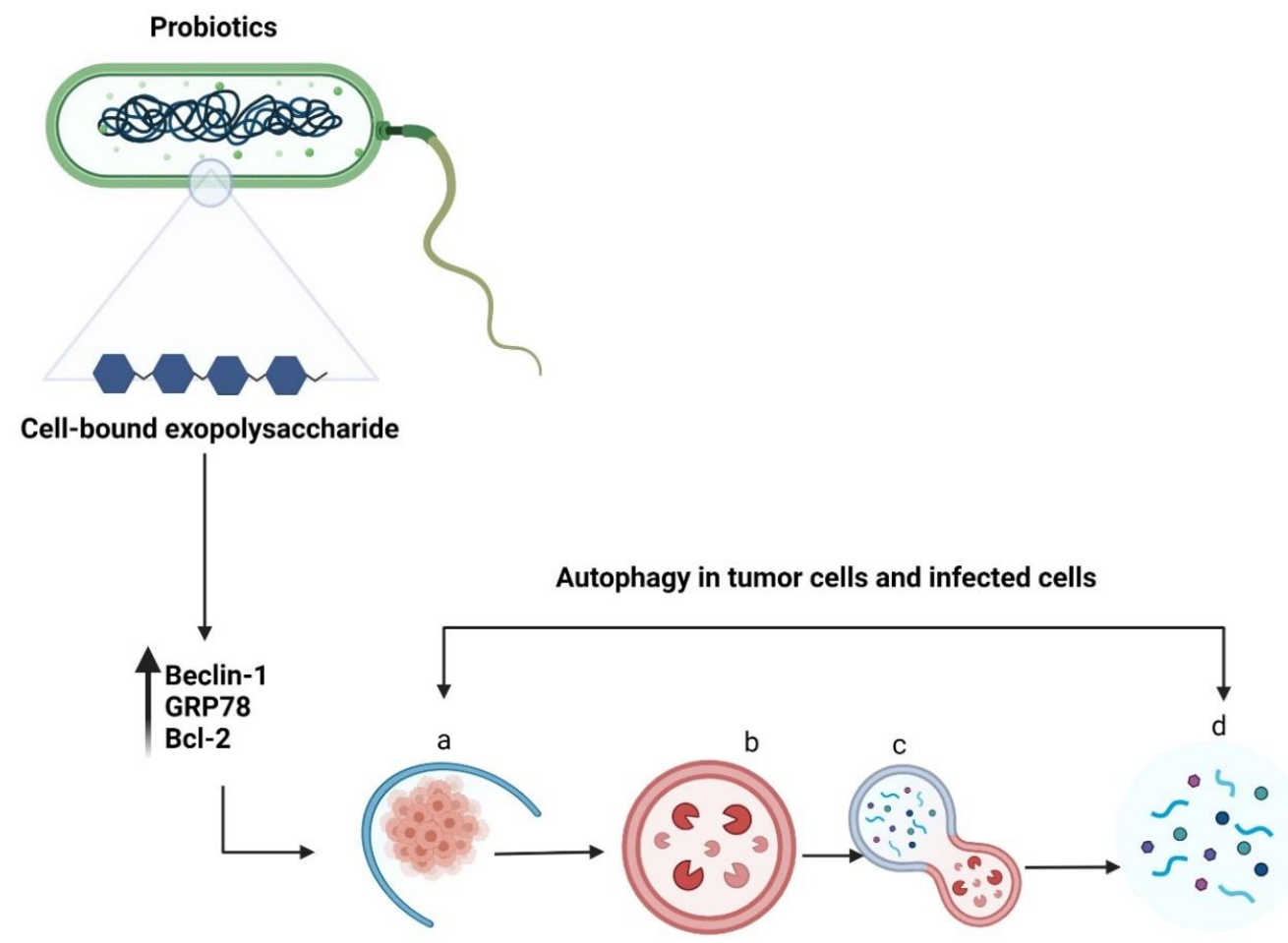

Figure 5. Schematic representation of autophagy in tumour cells or infected cells. The cell-bound exopolysaccharide of probiotic bacteria induces autophagy by upregulating Beclin-1, GRP78, and Bcl-2 genes. The sequential events occurring during autophagy include (a) sequestration (b) transport to lysosomes, (c) degradation, and (d) utilization of degradation products. Created with BioRender.com, accessed on 28 December 2021. 


\section{Probiotics as Potential Antimutagens}

There are numerous agents that can cause DNA damage and mutations, which eventually lead to cancer [59]. Such agents that cause mutations are called mutagens. Carcinogenicity and mutagenicity are closely associated with each other [60]. Chemicals, ionizing and nonionizing radiations, and viruses are the widely known mutagens that cause cancers [61]. Probiotics are potential antimutagenic agents owing to their metabolites [62]. A study investigated the antimutagenic effects of probiotics against the mutagens sodium azide and benzopyrene and reported that probiotics have a binding potential for mutagens and are detoxifying antimutagens [63]. Of late, researchers are exploring the potential of probiotics as an alternate preservative and detoxifying agent [64-66]. The antimutagenic activity of Lactobacillus rhamnosus against the mutagen acridine orange has been previously analyzed and confirmed [67]. Table 1 presents the mutagen, antimutagenic microorganisms, and the source from which they are isolated.

Table 1. List of mutagens, antimutagenic probiotics, and sources of probiotics.

\begin{tabular}{|c|c|c|c|}
\hline Mutagen & Antimutagenic Microorganism & Source & Reference \\
\hline Sodium azide and benzopyrene & $\begin{array}{c}\text { Lactobacillus alimentarius DDL 48, Enterococcus } \\
\text { faecium DDE 39, Bifidobacterium bifidum DDBA, } \\
\text { and Lactobacillus reuteri DDL } 19\end{array}$ & Goat milk & [63] \\
\hline Acridine orange & Lactobacillus rhamnosus & Infant feces & [67] \\
\hline $\begin{array}{l}\text { Heterocyclic amine binding and } \\
\text { N-nitrosamine }\end{array}$ & Lactobacillus plantarum CM4 & Thai fermented food products & {$[68]$} \\
\hline Benzo[a]pyrene and sodium azide & Lactobacillus and Bifidobacterium & ATCC & [69] \\
\hline 4-nitro-O-phenylenediamine & Lactobacillus acidophilus and Bifidobacteria & & [20] \\
\hline Trp-P-1 and Trp-P-2 & Bifidobacterium longum & Milk & [70] \\
\hline Benzopyrene & $\begin{array}{l}\text { Bifidobacterium lactis Bb-12, Bifidobacterium } \\
\text { longum CCRC } 14634\end{array}$ & & [71] \\
\hline N-methyl-N'-nitro-N-nitrosoguanidine & $\begin{array}{c}\text { Lactobacillus, Streptococcus, Lactococcus, and } \\
\text { Bifidobacterium }\end{array}$ & & [72] \\
\hline $\begin{array}{c}\text { N-methyl, N'-nitro, N-nitroso-guanidine, and } \\
\text { 3,2'-dimethyl-4-amino-biphenyl }\end{array}$ & $\begin{array}{l}\text { Lactobacillus helveticus CH65, Lactobacillus } \\
\text { acidophilus BG2FO4, Streptococcus salivarius ssp., } \\
\text { and Lactobacillus delbrueckii sp. bulgaricus 191R }\end{array}$ & Fermented milk & [73] \\
\hline 2-nitroflourene and nitroquinoline-1-oxide & Lactobacillus paracasei subsp. tolerans JG22 & Pepper leaves Jangajji & [74] \\
\hline N-methyl-N'-nitro-N-nitrosoguanidine & Bifidobacterium breve and Bifidobacterium longum & Human infant stool & [75] \\
\hline 4-nitro-O-phenylenediamine & Lactobacillus plantarum KLAB21 & $\begin{array}{c}\text { Kimchi (Korean } \\
\text { fermented vegetables) }\end{array}$ & [76] \\
\hline $\begin{array}{l}\text { 3-amino-1-methyl-5H-pyrido[4,3-b]indole } \\
\text { (Trp-P2) }\end{array}$ & $\begin{array}{l}\text { Lactobacillus acidophilus LA106 (LA2) and } \\
\text { Lactococcus lactis subsp. lactis L11103 }\end{array}$ & Milk & [77] \\
\hline $\begin{array}{c}\text { 2-(2-furyI)-3-(5-nitro-2-furyl) acrylamide and } \\
\text { 4-nitroquinoline-N-oxide }\end{array}$ & $\begin{array}{l}\text { Lactobacillus bulgaricus and } \\
\text { Streptococcus thermophilus }\end{array}$ & Milk & [78] \\
\hline $\begin{array}{l}\text { 1,1-diphenyl-2-picrylhydrazyl and } \\
\text { 2,2'-azino-bis(3-ethylbenzothiazoline- } \\
\text { 6-sulphonic acid) }\end{array}$ & $\begin{array}{c}\text { Lactobacillus acidophilus, Lactobacillus casei, and } \\
\text { Lactobacillus paracasei subsp. paracasei }\end{array}$ & Yogurt & [79] \\
\hline Furazolidone & $\begin{array}{l}\text { Bifidobacterium lactis Bb-12 and } \\
\text { Lactobacillus acidophilus }\end{array}$ & & [80] \\
\hline N-methyl-N0-nitro-N-nitrosoguanidine & Lactobacillus rhamnosus & Vaginal mucosa & [81] \\
\hline Heterocyclic aromatic amines & Lactobacillus helveticus & Milk & [82] \\
\hline $\begin{array}{l}\text { Sodium azide (NaN3) and } \\
\text { 2-nitrofluorene (2-NF) }\end{array}$ & Lactobacillus plantarum & Fermented durian & [83] \\
\hline
\end{tabular}

The antimutagenic effect of probiotics is well-documented in the literature. The components of the probiotic cell wall, such as carbohydrates, proteins, lipids, and teichoic acids, are responsible for binding to the mutagens, and this interaction is hydrophilic [67,82]. Apart from the cell wall components, the glycoproteins secreted extracellularly [84] and organic acids, such as acetic, butyric, lactic, and pyruvic acids [20], also exhibit antimutagenic properties. For this reason, probiotics are used for the detoxification of food items and the treatment of some gastrointestinal disorders [85]. 


\section{Probiotics-Mediated Tumour Suppressor Reactivation}

Tumour suppressors slow down cell division, repair damaged DNA, and regulate apoptosis [86]. The tumour suppressor genes present in humans are $A P C, B R C A 1, B R C A 2$, $p 16, p 21, p 53, R b$, and $V H L[87,88]$. Any defects or mutations in these genes can lead to cancers. Hence, it is crucial to reactivate tumour suppressor genes that are turned off by cancer cells. Many clinical trials are underway to determine if probiotics can be used as a potentially novel targeted biotherapy for cancers $[89,90]$. Sharma et al. demonstrated the involvement of short-chain fatty acids synthesized by probiotics in targeting tumour cells via the epigenetic regulation of the expression of tumour suppressor genes and oncogenes [91]. Epigenetic mechanisms alter gene expression without changing the primary DNA sequence [92]. Moreover, these mechanisms are heritable, reversible, and involve changes in DNA methylation, histone modifications, and small noncoding microRNAs (miRNAs) [92]. Metabiotics extracted from the probiotic L. rhamnosus MD inhibit colorectal cancer by upregulating the expression of the tumour suppressor gene p53 [93]. L. rhamnosus MD 14, L. acidophilus, and L. rhamnosus GG were shown to upregulate the expression of tumour suppressor genes in 1,2-dimethylhydrazine-induced experimental colon carcinogenesis model [94]. Bifidobacterium longum, isolated from breast milk, induced the expression of the tumour suppressor miRNAs miR-145 and miR-15 in murine colorectal cancer [95]. Kumar et al. emphasized that probiotic metabolites prevent colon cancer via epigenetic mechanisms and the metabiotics of probiotics play a key role in this process [96]. However, research related to the reactivation of tumour suppressors by probiotics is still in its infancy.

\section{Downregulation of Oncogene Expression by Probiotics}

Oncogene expression causes cells to exhibit the properties of tumour cells, whereas proto-oncogenes are the normal nonmutated forms of oncogenes [97]. Proto-oncogenes are the precursors of oncogenes and are converted into oncogenes upon mutation [98]. The downregulation of oncogenes is one of the druggable targets of cancer therapy [99]. Several proto-oncogenes have been identified in different organisms by the virtue of structural homology to retroviral oncogenes [100]. The important proto-oncogenes in humans include Ras, HER2, Myc, cyclin D, cyclin E, $\beta$-catenin, and MITF (microphthalmia-associated transcription factor) [81]. Several reports have demonstrated the tumour-suppressive activity of probiotics via the downregulation of oncogenes [101,102]. The probiotic bacteria Lactobacillus crispatus and L. rhamnosus modulate cancers by altering the expression of mTOR-related genes and modulating the Wnt/ $\beta$-catenin pathways [103]. Azam et al. showed that the culture supernatants of L. acidophilus and L. crispatus can downregulate cancer-testis gene expression in vitro [101]. A combination of probiotics and celecoxib (a nonsteroidal anti-inflammatory drug) can also downregulate the KRAS proto-oncogene, decreasing the incidence of colon cancer [94]. Understanding the mechanism of KRAS downregulation by probiotics could be beneficial for patients with $R A S$-associated cancers. Hosseini et al. revealed that the bacteriocin nisin as well as the cytoplasmic extract and cell wall of Lactococcus lactis decreased cyclin D1 expression, thereby inhibiting the proliferation of SW480 cells [104]. Lipoteichoic acid extracted from L. plantarum downregulated MITF [105]. Overall, approaches involving the regulation of oncogene expression using probiotics and their metabolites are being extensively investigated.

\section{Role of Probiotics in Preventing Metastasis}

Metastasis involves the detachment of tumour cells from the primary tumour and their dissemination to other parts of the body [106]. Cancer patients can develop metastasis years after the diagnosis of the primary tumour [107]. Metastasis is the cause of death in $>90 \%$ of cancer patients [108]. It mainly occurs due to the epithelial-mesenchymal transition (EMT) of cancer cells [109], a physiological process by which epithelial cells attain the characteristics of mesenchymal cells, both physiologically and morphologically [110]. The metastasis of cancer cells can be divided into five steps: (1) infiltration of the base- 
ment membrane; (2) intravasation into the surrounding vasculature or lymphatic system; (3) persistence in the circulation; (4) extravasation to secondary tissue; and (5) colonization at secondary tumour sites [111]. The prevention of initial metastasis is crucial for improving the prognosis of cancer patients. Additionally, the inhibition of additional metastases in patients with metastases is helpful for improving the prognosis [112]. Several reports have highlighted the critical factors involved in metastasis, such as the interruption of cell-cell adhesion, EMT, tumour microenvironment, and cancer stem cell maintenance, as well as the antimetastatic effects of probiotics (Figure 6) [26]. Cell-free supernatants of probiotic L. casei and L. rhamnosus GG reduced the incidence of colon cancer as well as its metastatic effects by decreasing the levels of matrix metalloproteinase-9 (MMP-9) and increasing the levels of tight junction protein ZO-1 [113,114]. Additionally, the cell-free supernatant of L. plantarum YYC-3 inhibited the metastasis of colon cancer cells by suppressing the vascular endothelial growth factor (VEGF)-MMP2/9 signalling pathway [115]. VEGF is a signalling protein that promotes the growth of new blood vessels [116], whereas matrix metalloproteinases (MMPs) degrade the extracellular matrix [117]. Therefore, the suppression of the VEGF-MMP2/9 signalling pathway can inhibit the degradation of the basement membrane, which is the first step in metastasis. E-cadherin is the most important protein for cell-cell adhesion [118]. Li et al. observed a significant upregulation in E-cadherin levels in HeLa cells and the inhibition of cancer cell migration in response to probiotic treatment [119]. Additionally, probiotic treatment lowered the expression of EMT-related markers (Snail-1 and ZEB-1) in pancreatic cancer mouse models [120]. Kefir, a probiotic fermented food, showed antimetastatic and antiangiogenic effects in murine breast cancer cells, leading to the upregulation of tissue inhibitors of MMPs (TIMPs) [121]. Hence, probiotics play a key role in preventing metastasis.

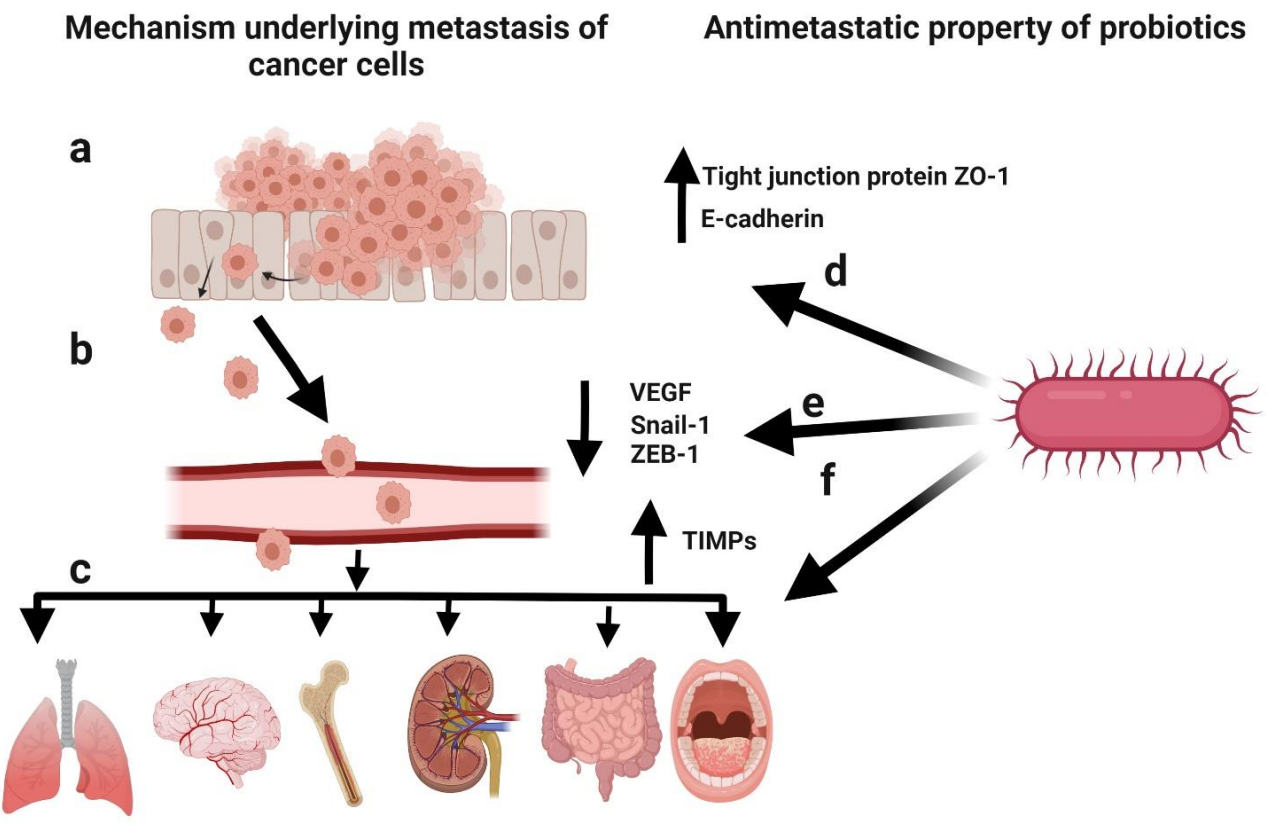

Figure 6. Schematic representation of the mechanism underlying cancer metastasis and the antimetastatic potential of probiotics. (a) Infiltration of cancer cells through the basement membrane. (b) Intravasation into the surrounding vasculature or lymphatic system. (c) Extravasation to secondary tissue and colonization as secondary tumours. (d) Elevated levels of the tight junction protein ZO-1 and E-cadherin induced by probiotics to inhibit metastasis. (e) Decreased levels of epithelialmesenchymal transition (EMT)-related markers (Snail-1 and ZEB-1) and vascular endothelial growth factor (VEGF) induced by probiotics to inhibit metastasis. (f) Upregulation of tissue inhibitors of matrix metalloproteinases (TIMPs) by probiotics to inhibit metastasis. Created with BioRender.com, accessed on 28 December 2021. 


\section{Kinase Inhibition by Probiotics}

Kinases and phosphatases are enzymes that add and remove phosphate groups, respectively [122]. Phosphorylation events alter other proteins by adding the terminal $\gamma$-phosphate group of adenosine triphosphate (ATP) to threonine, serine, and tyrosine residues [123]. Approximately 518 kinase-encoding and 156 phosphatase-encoding genes are estimated to be present in the human genome [124,125]. Kinases play a major role in various aspects of tumour biology, such as cell propagation, motility, metabolism, new blood vessel formation, and metastasis [126]. Hence, kinases are a potential therapeutic target for cancers [127]. A few studies have demonstrated the use of probiotics and their metabolites as kinase inhibitors for treating diarrhoea after cancer therapy $[128,129]$. Seth et al. demonstrated that probiotic secretory proteins protect the intestinal epithelial tight junctions and the barrier function from hydrogen peroxide-induced insult via a protein kinase C (PKC) and MAPK-dependent mechanism [130]. L. plantarum induces apoptosis by downregulating MAPKs and upregulating phosphatases [46]. Lactobacillus facilitated natural killer cell activity by producing tumour necrosis factor-associated apoptosis-inducing ligand, i.e., TNFAIL, in prostate cancer cell lines [131]. Further research efforts are targeting the kinase inhibitor activity of probiotics.

\section{Bacteriocin as a Potent Anticancer Agent}

A plethora of research has demonstrated the antioxidant and anti-inflammatory activities of metabiotics of probiotics, which forms the basis for their anticancer effects. Han et al. analysed the anti-inflammatory activity of Lactobacillus lactis NK34 strain in RAW 264.7 cells [132]. A significant reduction in the proliferation of cells and the production of nitric oxide and proinflammatory cytokines was observed [132]. The strains Lactobacillus mucosae AN1 and Lactobacillus fermentum SNR1 significantly reduced paw oedema and increased the expression of the anti-inflammatory cytokine IL-10 in comparison with the proinflammatory cytokine IL-6 [133]. Chooruk et al. reported that L. fermentum, Lactobacillus paracasei, and L. rhamnosus strains exhibit significant antioxidant activity [134]. Another study conducted by Yang et al. showed that probiotics downregulated the enzymes producing reactive oxygen species (ROS), glutathione (GSH), and butyrate [135]. Previous studies indicated that probiotics could produce folate $[136,137]$ and bacteriocin, a low molecular weight protein with anti-inflammatory, anticancer, and immunomodulatory properties [138-141].

There are three major types of bacteriocins: class I $(<5 \mathrm{kDa})$, class II $(<10 \mathrm{kDa})$, and class III ( $>30 \mathrm{kDa})$ [142]. Bacteriocin is an FDA-approved compound that is commonly used in the food and pharmaceutical industry [143]. The anticancer activity of bacteriocin is well-documented in the literature [144-146]. Interestingly, bacteriocin specifically targets cancer cells and spares normal cells [147]. Normal cells are asymmetric in nature owing to the distribution of phospholipids on the inner and outer surfaces of the cell [148]. The outer layer of the normal cells is made up of sphingomyelin and phosphatidylcholine, which are neutral choline-containing zwitterionic phospholipids [149]. The inner layer is made up of phosphatidylserine and phosphatidylethanolamine, which are aminophospholipids [150]. On the contrary, cancer cells lack asymmetry as a result of changes in their phospholipids and carry a negative charge due to the presence of O-glycosylated mucins, heparin sulphates, and anionic phosphatidylserine [151]. Moreover, cancer cells have higher membrane fluidity and a number of microvilli compared with normal cells, resulting in an increased surface area [152]. Therefore, bacteriocin can preferentially bind to negatively charged tumour cells rather than neutrally charged normal cells [37]. Several studies have investigated cellular responses to bacteriocin in vitro (Table 2). 
Table 2. Bacteriocins and their anticancer activity in select cell lines.

\begin{tabular}{cccc}
\hline Bacteriocin & Source of Bacteriocin & Cell Lines & Reference \\
\hline Enterocin LNS18 & Enterococcus & HepG2 (liver cancer) & [141] \\
LHH1 & Lactobacillus casei HZ1 & MGC803, HCT116, and C666-1 (multiple origins) & [153] \\
Microcin E492 & Klebsiella pneumoniae & HeLa (cervical cancer) & [154] \\
Laterosporulin10 & Brevibacillus sp. strain SKDU10 & MCF-7, HEK293T, HT1080, HeLa, and H1299 & [141] \\
\hline
\end{tabular}

\section{Drug Delivery Systems for Bacteriocin}

Despite having excellent antimicrobial, antioxidant, and anticancer activities, bacteriocins may not be optimal for use as a drug delivery system. They can be easily digested by proteolytic enzymes in the intestinal tract. Hence, there is a need to examine alternative systems, such as liposomal delivery, for the delivery of antimicrobial and anticancer peptides (Figure 7) $[155,156]$. Nanotechnology is a valuable strategy to improve bacteriocin formulations and incorporate them into nanoparticles for delivery $[157,158]$. Nisin, a bacteriocin, has been successfully used in implants and delivered in vivo to prevent the growth of Staphylococcus aureus [159]. Hydrogels can be loaded with bacteriocins prior to delivery $[155,160]$. Bacteriocins can also be administered in the form of oral tablets [161] and chewing gum [162]. Additionally, bacteriocins can be used to coat medical devices, such as catheters, to prevent infections by inhibiting the adhesion of bacteria to their surfaces [163].

\section{Drug delivery system of bacteriocin}

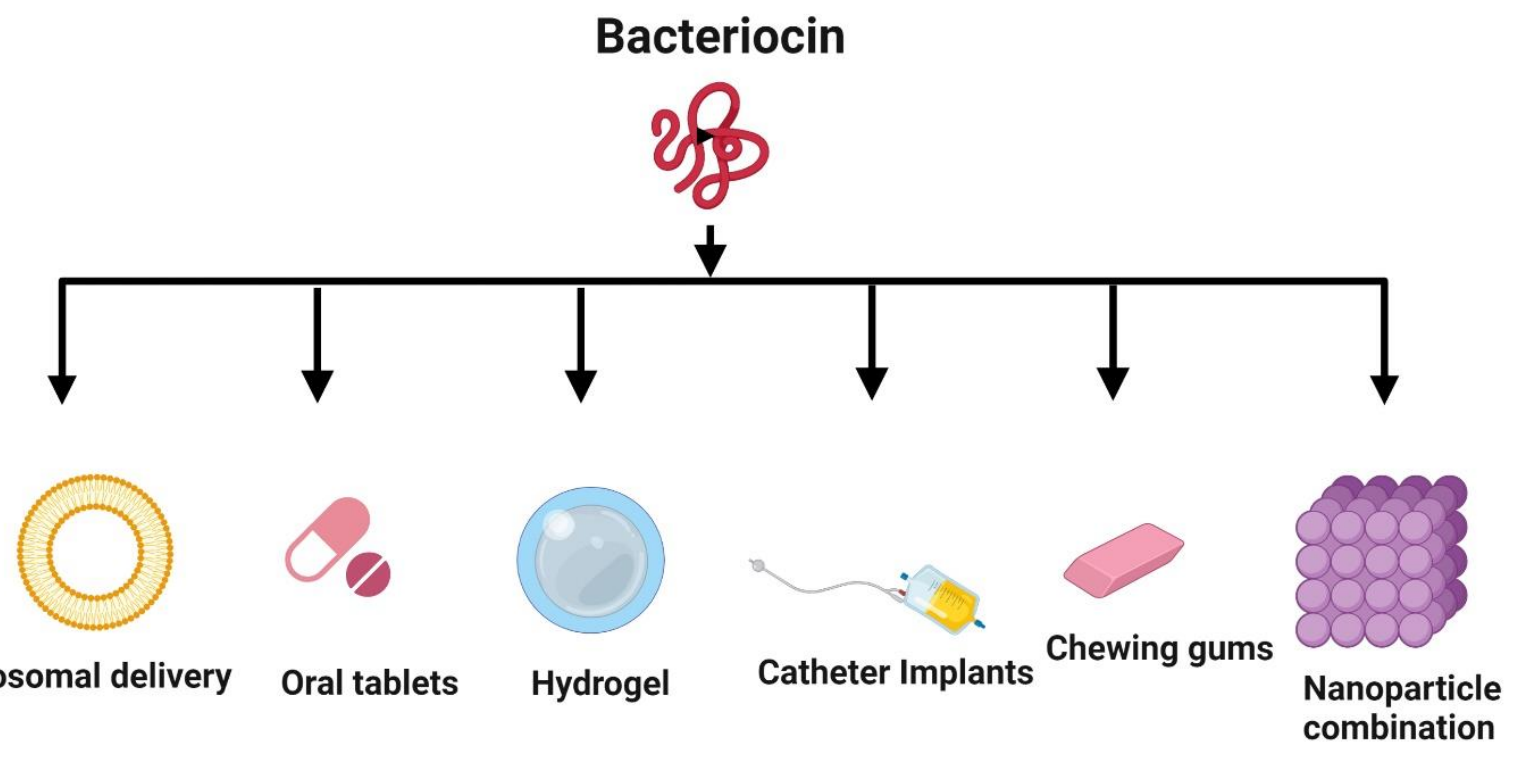

Figure 7. Novel delivery systems for bacteriocin. The strategies to deliver bacteriocin include liposomal delivery, oral administration (tablets and chewing gum), hydrogel embedding, medical device coating (e.g., catheter), and nanoparticle encapsulation. Created with BioRender.com, accessed on 28 December 2021.

\section{Clinical Trials with Probiotics}

The World Health Organization defines clinical trial as "any research study that prospectively assigns human participants or groups of humans to one or more healthrelated interventions to evaluate the effects on health outcomes" [164]. While clinical trials investigating probiotics date back to the 1900s, the number of trials has increased significantly in recent years, with $>100$ studies being registered each year since 2010. According to ClinicalTrials.gov, accessed on 28 December 2021 and the International Clinical 
Trials Registry Platform, 323 and 1157 studies, respectively, are currently investigating the role of probiotics in improving oral health, gut microbiota, immune regulation, $\mathrm{pH}$ maintenance, and antimicrobial/anticancer activity throughout the United States, Europe, and Asia $[165,166]$. L. rhamnosus GG and Bifidobacterium animalis were the most frequently registered probiotic strains [167]. In addition, studies in children are higher in number than those in the elderly population according to ClinicalTrials.gov, accessed on 28 December 2021 [167]. A major limitation of the current studies is that many of them are observational. Nevertheless, immune regulation by probiotics has been demonstrated in studies investigating checkpoint inhibition as a potential anticancer therapy and colitis as an adverse effect of the therapy [167]. The ongoing research efforts are focused on studying the role of probiotics in treating gastrointestinal, metabolic, neurological, autoimmune, and communicable diseases [167]. Additionally, clinical trials have also highlighted the efficacy of probiotic strains in reducing the side effects of cancer-related microbiota dysbiosis [168]. More clinical trials that are inclusive of diverse populations and have a good statistical power are warranted to further explore the potential of probiotics in improving human health.

\section{Conclusions and Future Perspectives}

Probiotics have demonstrated efficacy (although variable, depending upon the strain, dosage, and duration of treatment) against various cancer types owing to their roles in antioxidation, immunomodulation, apoptosis induction, antimutagenicity, oncogene expression downregulation, autophagy induction, kinase inhibition, tumour suppressor reactivation, and metastasis prevention. A growing body of evidence suggests that probiotics can be used as an adjunctive therapy for cancer patients receiving chemotherapy. Although these findings are promising, large-scale randomized controlled trials are needed to determine the overall safety and efficacy of the formulations in treating cancer. Any regulatory issues and potential risks should also be addressed. The identification of specific probiotic strains that have the most benefits and minimal or no adverse effects in the context of cancer will be an important milestone in the development of a personalized approach for each patient with cancer. Probiotics induce tumour cell apoptosis and inhibit tumour cell proliferation and metastasis. However, considering that most of the current research on probiotics and cancer is limited to gastrointestinal tumours, the specific mechanism of probiotics against tumours has not been fully elucidated. As such, the therapeutic effects of probiotics must be carefully considered. As additional supplementary active microorganisms, the adverse reactions of probiotics, gastrointestinal side effects, skin reactions, access to antibiotic resistance genes, harmful effects of probiotic metabolites, and abnormal stimulation of the immune system must be evaluated.

Author Contributions: Conceptualization, V.S., P.G. and B.-C.A.; software, M.P.J.; writing—original draft preparation, V.S.; writing—review and editing, V.S., B.A.V.M., R.L.R., M.P.J., S.G., R.K., P.G. and B.-C.A.; funding acquisition, R.L.R. and P.G.; All authors have read and agreed to the published version of the manuscript.

Funding: This research was supported by Basic Science Research Program through the National Research Foundation of Korea (NRF) funded by the Ministry of Education (NRF-2019R111A3A01063308, NRF-2019R1I1A1A01061296, and NRF-2021R1I1A1A01040732).

Institutional Review Board Statement: Not Applicable.

Informed Consent Statement: Not Applicable.

Data Availability Statement: Not Applicable.

Conflicts of Interest: The authors declare that no competing interest exist. 


\section{References}

1. Gasbarrini, G.; Bonvicini, F.; Gramenzi, A. Probiotics History. J. Clin. Gastroenterol. 2016, 50, S116-S119, Proceedings from the 8th Probiotics, Prebiotics\&New Foods for Microbiota and Human Health meeting held in Rome, Italy on 13-15 September 2015. [CrossRef] [PubMed]

2. Talwar, G.P. Textbook of Biochemistry, Biotechnology, Allied And Molecular Medicine; PHI Learning Pvt. Ltd.: New Delhi, India, 2015; ISBN 978-81-203-5125-7.

3. Jahanshahi, M.; Maleki Dana, P.; Badehnoosh, B.; Asemi, Z.; Hallajzadeh, J.; Mansournia, M.A.; Yousefi, B.; Moazzami, B.; Chaichian, S. Anti-Tumor Activities of Probiotics in Cervical Cancer. J. Ovarian Res. 2020, 13, 68. [CrossRef] [PubMed]

4. Mackowiak, P.A. Recycling Metchnikoff: Probiotics, the Intestinal Microbiome and the Quest for Long Life. Front. Public Health 2013, 1, 52. [CrossRef]

5. Morelli, L.; Capurso, L. FAO/WHO Guidelines on Probiotics: 10 Years Later. J. Clin. Gastroenterol. 2012, 46, S1-S2. [CrossRef]

6. Śliżewska, K.; Markowiak-Kopeć, P.; Śliżewska, W. The Role of Probiotics in Cancer Prevention. Cancers 2020, 13, 20. [CrossRef]

7. Lu, K.; Dong, S.; Wu, X.; Jin, R.; Chen, H. Probiotics in Cancer. Front. Oncol. 2021, 11, 638148. [CrossRef]

8. Fuller, R. Probiotics in Human Medicine. Gut 1991, 32, 439-442. [CrossRef] [PubMed]

9. Corcoran, B.M.; Stanton, C.; Fitzgerald, G.F.; Ross, R.P. Survival of Probiotic Lactobacilli in Acidic Environments Is Enhanced in the Presence of Metabolizable Sugars. Appl. Environ. Microbiol. 2005, 71, 3060-3067. [CrossRef]

10. Singhal, N.; Maurya, A.K.; Mohanty, S.; Kumar, M.; Virdi, J.S. Evaluation of Bile Salt Hydrolases, Cholesterol-Lowering Capabilities, and Probiotic Potential of Enterococcus Faecium Isolated From Rhizosphere. Front. Microbiol. 2019, $10,1567$. [CrossRef]

11. Han, S.; Lu, Y.; Xie, J.; Fei, Y.; Zheng, G.; Wang, Z.; Liu, J.; Lv, L.; Ling, Z.; Berglund, B.; et al. Probiotic Gastrointestinal Transit and Colonization After Oral Administration: A Long Journey. Front. Cell. Infect. Microbiol. 2021, 11, 102. [CrossRef]

12. Lebeer, S.; Vanderleyden, J.; De Keersmaecker, S.C.J. Host Interactions of Probiotic Bacterial Surface Molecules: Comparison with Commensals and Pathogens. Nat. Rev. Microbiol. 2010, 8, 171-184. [CrossRef]

13. Bodera, P.; Chcialowski, A. Immunomodulatory Effect of Probiotic Bacteria. Recent Pat. Inflamm. Allergy Drug Discov. 2009, 3, 58-64. [CrossRef]

14. Gerbaldo, G.A.; Barberis, C.; Pascual, L.; Dalcero, A.; Barberis, L. Antifungal Activity of Two Lactobacillus Strains with Potential Probiotic Properties. FEMS Microbiol. Lett. 2012, 332, 27-33. [CrossRef]

15. Fijan, S. Microorganisms with Claimed Probiotic Properties: An Overview of Recent Literature. Int. J. Environ. Res. Public. Health 2014, 11, 4745-4767. [CrossRef]

16. Waigankar, S.S.; Patel, V. Role of Probiotics in Urogenital Healthcare. J. Life Health 2011, 2, 5-10. [CrossRef] [PubMed]

17. Soccol, C.R.; Vandenberghe, L.P. de de Souza Vandenberghe, L.P.; Spier, M.R.; Medeiros, A.B.P.; Yamaguishi, C.T.; Lindner, J.D.D.; Pandey, A.; Thomaz-Soccol, V. The Potential of Probiotics: A Review. Food Technol. Biotechnol. 2010, 48, 413-434.

18. Górska, A.; Przystupski, D.; Niemczura, M.J.; Kulbacka, J. Probiotic Bacteria: A Promising Tool in Cancer Prevention and Therapy. Curr. Microbiol. 2019, 76, 939-949. [CrossRef] [PubMed]

19. Tiptiri-Kourpeti, A.; Spyridopoulou, K.; Santarmaki, V.; Aindelis, G.; Tompoulidou, E.; Lamprianidou, E.E.; Saxami, G.; Ypsilantis, P.; Lampri, E.S.; Simopoulos, C.; et al. Lactobacillus Casei Exerts Anti-Proliferative Effects Accompanied by Apoptotic Cell Death and Up-Regulation of TRAIL in Colon Carcinoma Cells. PLoS ONE 2016, 11, e0147960. [CrossRef]

20. Lankaputhra, W.E.; Shah, N.P. Antimutagenic Properties of Probiotic Bacteria and of Organic Acids. Mutat. Res. 1998, 397, 169-182. [CrossRef]

21. Thilakarathna, W.P.D.W.; Rupasinghe, H.P.V.; Ridgway, N.D. Mechanisms by Which Probiotic Bacteria Attenuate the Risk of Hepatocellular Carcinoma. Int. J. Mol. Sci. 2021, 22, 2606. [CrossRef] [PubMed]

22. Kim, Y.; Oh, S.; Yun, H.S.; Oh, S.; Kim, S.H. Cell-Bound Exopolysaccharide from Probiotic Bacteria Induces Autophagic Cell Death of Tumour Cells. Lett. Appl. Microbiol. 2010, 51, 123-130. [CrossRef] [PubMed]

23. Ravi, A.V.; Musthafa, K.S.; Jegathammbal, G.; Kathiresan, K.; Pandian, S.K. Screening and Evaluation of Probiotics as a Biocontrol Agent against Pathogenic Vibrios in Marine Aquaculture. Lett. Appl. Microbiol. 2007, 45, 219-223. [CrossRef]

24. Uccello, M.; Malaguarnera, G.; Basile, F.; D’agata, V.; Malaguarnera, M.; Bertino, G.; Vacante, M.; Drago, F.; Biondi, A. Potential Role of Probiotics on Colorectal Cancer Prevention. BMC Surg. 2012, 12, S35. [CrossRef]

25. Lamichhane, P.; Maiolini, M.; Alnafoosi, O.; Hussein, S.; Alnafoosi, H.; Umbela, S.; Richardson, T.; Alla, N.; Lamichhane, N.; Subhadra, B.; et al. Colorectal Cancer and Probiotics: Are Bugs Really Drugs? Cancers 2020, 12, 1162. [CrossRef]

26. Motevaseli, E.; Dianatpour, A.; Ghafouri-Fard, S. The Role of Probiotics in Cancer Treatment: Emphasis on Their In Vivo and In Vitro Anti-Metastatic Effects. Int. J. Mol. Cell. Med. 2017, 6, 66-76. [CrossRef]

27. Shenderov, B.A. Metabiotics: Novel Idea or Natural Development of Probiotic Conception. Microb. Ecol. Health Dis. 2013, 24. [CrossRef] [PubMed]

28. Lebeer, S.; Bron, P.A.; Marco, M.L.; Van Pijkeren, J.-P.; O'Connell Motherway, M.; Hill, C.; Pot, B.; Roos, S.; Klaenhammer, T. Identification of Probiotic Effector Molecules: Present State and Future Perspectives. Curr. Opin. Biotechnol. 2018, 49, $217-223$. [CrossRef] [PubMed]

29. Kumar, M.; Nagpal, R.; Verma, V.; Kumar, A.; Kaur, N.; Hemalatha, R.; Gautam, S.K.; Singh, B. Probiotic Metabolites as Epigenetic Targets in the Prevention of Colon Cancer. Nutr. Rev. 2013, 71, 23-34. [CrossRef]

30. Pfeffer, C.M.; Singh, A.T.K. Apoptosis: A Target for Anticancer Therapy. Int. J. Mol. Sci. 2018, 19, 448. [CrossRef] 
31. Alberts, B.; Johnson, A.; Lewis, J.; Raff, M.; Roberts, K.; Walter, P. Molecular Biology of the Cell, 4th ed.; Garland Science: New York, NY, USA, 2002; ISBN 978-0-8153-3218-3.

32. Lopez, J.; Tait, S.W.G. Mitochondrial Apoptosis: Killing Cancer Using the Enemy Within. Br. J. Cancer 2015, 112, 957-962. [CrossRef] [PubMed]

33. Igney, F.H.; Krammer, P.H. Death and Anti-Death: Tumour Resistance to Apoptosis. Nat. Rev. Cancer 2002, 2, 277-288. [CrossRef] [PubMed]

34. Kiraz, Y.; Adan, A.; Kartal Yandim, M.; Baran, Y. Major Apoptotic Mechanisms and Genes Involved in Apoptosis. Tumour Biol. J. Int. Soc. Oncodev. Biol. Med. 2016, 37, 8471-8486. [CrossRef] [PubMed]

35. Sharma, S.; Singh, R.L.; Kakkar, P. Modulation of Bax/Bcl-2 and Caspases by Probiotics during Acetaminophen Induced Apoptosis in Primary Hepatocytes. Food Chem. Toxicol. Int. J. Publ. Br. Ind. Biol. Res. Assoc. 2011, 49, 770-779. [CrossRef]

36. Karimi Ardestani, S.; Tafvizi, F.; Tajabadi Ebrahimi, M. Heat-Killed Probiotic Bacteria Induce Apoptosis of HT-29 Human Colon Adenocarcinoma Cell Line via the Regulation of Bax/Bcl2 and Caspases Pathway. Hum. Exp. Toxicol. 2019, 38, $1069-1081$. [CrossRef]

37. Chumchalová, J.; Smarda, J. Human Tumor Cells Are Selectively Inhibited by Colicins. Folia Microbiol. 2003, 48, 111-115. [CrossRef] [PubMed]

38. Preet, S.; Bharati, S.; Panjeta, A.; Tewari, R.; Rishi, P. Effect of Nisin and Doxorubicin on DMBA-Induced Skin Carcinogenesis—a Possible Adjunct Therapy. Tumour Biol. J. Int. Soc. Oncodev.l Biol. Med. 2015, 36, 8301-8308. [CrossRef] [PubMed]

39. Konishi, H.; Fujiya, M.; Tanaka, H.; Ueno, N.; Moriichi, K.; Sasajima, J.; Ikuta, K.; Akutsu, H.; Tanabe, H.; Kohgo, Y. ProbioticDerived Ferrichrome Inhibits Colon Cancer Progression via JNK-Mediated Apoptosis. Nat. Commun. 2016, 7, 12365. [CrossRef]

40. Kadirareddy, R.H.; Vemuri, S.G.; Palempalli, U.M.D. Probiotic Conjugated Linoleic Acid Mediated Apoptosis in Breast Cancer Cells by Downregulation of NFkB. Asian Pac. J. Cancer Prev. APJCP 2016, 17, 3395-3403.

41. Khosrovan, Z.; Haghighat, S.; Mahdavi, M. The Probiotic Bacteria Induce Apoptosis in Breast and Colon Cancer Cells: An Immunostimulatory Effect. Immunoregulation 2020, 3, 37-50. [CrossRef]

42. Isazadeh, A.; Hajazimian, S.; Shadman, B.; Safaei, S.; Bedoustani, A.B.; Chavoshi, R.; Shanehbandi, D.; Mashayekhi, M.; Nahaei, M.; Baradaran, B. Anti-Cancer Effects of Probiotic Lactobacillus Acidophilus for Colorectal Cancer Cell Line Caco-2 through Apoptosis Induction. Pharm. Sci. 2020, 27, 262-267. [CrossRef]

43. Yavari, M.; Ahmadizadeh, C. Effect of the Cellular Extract of Co-Cultured Lactobacillus Casei on BAX and Human $\beta$-Defensin 2 Genes Expression in HT29 Cells. Horiz. Med. Sci. 2020, 26, 364-381. [CrossRef]

44. Joo, N.E.; Ritchie, K.; Kamarajan, P.; Miao, D.; Kapila, Y.L. Nisin, an Apoptogenic Bacteriocin and Food Preservative, Attenuates HNSCC Tumorigenesis via CHAC1. Cancer Med. 2012, 1, 295-305. [CrossRef]

45. Jan, G.; Belzacq, A.-S.; Haouzi, D.; Rouault, A.; Métivier, D.; Kroemer, G.; Brenner, C. Propionibacteria Induce Apoptosis of Colorectal Carcinoma Cells via Short-Chain Fatty Acids Acting on Mitochondria. Cell Death Differ. 2002, 9, 179-188. [CrossRef] [PubMed]

46. Asoudeh-Fard, A.; Barzegari, A.; Dehnad, A.; Bastani, S.; Golchin, A.; Omidi, Y. Lactobacillus Plantarum Induces Apoptosis in Oral Cancer KB Cells through Upregulation of PTEN and Downregulation of MAPK Signalling Pathways. BioImpacts BI 2017, 7 , 193-198. [CrossRef] [PubMed]

47. Zhang, G.; Zhang, J.; Wang, X.; Yang, W.; Sun, Z.; Kumar, C.N.; Guan, H.; Guan, J. Apoptosis of Human Tongue Squamous Cell Carcinoma Cell (CAL-27) Induced by Lactobacillus Sp. A-2 Metabolites. J. Appl. Oral Sci. Rev. FOB 2014, 22, 282-286. [CrossRef]

48. Zhang, M.; Wang, F.; Jiang, L.; Liu, R.; Zhang, L.; Lei, X.; Li, J.; Jiang, J.; Guo, H.; Fang, B.; et al. Lactobacillus Salivarius REN Inhibits Rat Oral Cancer Induced by 4-Nitroquioline 1-Oxide. Cancer Prev. Res. 2013, 6, 686-694. [CrossRef] [PubMed]

49. Stashenko, P.; Yost, S.; Choi, Y.; Danciu, T.; Chen, T.; Yoganathan, S.; Kressirer, C.; Ruiz-Tourrella, M.; Das, B.; Kokaras, A.; et al. The Oral Mouse Microbiome Promotes Tumorigenesis in Oral Squamous Cell Carcinoma. mSystems 2019, 4, e00323-19. [CrossRef] [PubMed]

50. La Rosa, G.R.M.; Gattuso, G.; Pedullà, E.; Rapisarda, E.; Nicolosi, D.; Salmeri, M. Association of Oral Dysbiosis with Oral Cancer Development. Oncol. Lett. 2020, 19, 3045-3058. [CrossRef]

51. Li, X.; He, S.; Ma, B. Autophagy and Autophagy-Related Proteins in Cancer. Mol. Cancer 2020, 19, 12. [CrossRef] [PubMed]

52. Yang, Z.J.; Chee, C.E.; Huang, S.; Sinicrope, F.A. The Role of Autophagy in Cancer: Therapeutic Implications. Mol. Cancer Ther. 2011, 10, 1533-1541. [CrossRef]

53. Jogalekar, M.P.; Veerabathini, A.; Gangadaran, P. Recent Developments in Autophagy-Targeted Therapies in Cancer. Exp. Biol. Med. 2021, 246, 207-212. [CrossRef]

54. Tran, S.; Fairlie, W.D.; Lee, E.F. BECLIN1: Protein Structure, Function and Regulation. Cells 2021, 10, 1522. [CrossRef]

55. Wang, H.; Cheng, X.; Zhang, L.; Xu, S.; Zhang, Q.; Lu, R. A Surface-Layer Protein from Lactobacillus Acidophilus NCFM Induces Autophagic Death in HCT116 Cells Requiring ROS-Mediated Modulation of MTOR and JNK Signaling Pathways. Food Funct. 2019, 10, 4102-4112. [CrossRef] [PubMed]

56. Parzych, K.R.; Klionsky, D.J. An Overview of Autophagy: Morphology, Mechanism, and Regulation. Antioxid. Redox Signal. 2014, 20, 460-473. [CrossRef] [PubMed]

57. Bednarczyk, M.; Zmarzły, N.; Grabarek, B.; Mazurek, U.; Muc-Wierzgoń, M. Genes Involved in the Regulation of Different Types of Autophagy and Their Participation in Cancer Pathogenesis. Oncotarget 2018, 9, 34413-34428. [CrossRef] [PubMed]

58. Yim, W.W.-Y.; Mizushima, N. Lysosome Biology in Autophagy. Cell Discov. 2020, 6, 1-12. [CrossRef] [PubMed] 
59. Golemis, E.A.; Scheet, P.; Beck, T.N.; Scolnick, E.M.; Hunter, D.J.; Hawk, E.; Hopkins, N. Molecular Mechanisms of the Preventable Causes of Cancer in the United States. Genes Dev. 2018, 32, 868-902. [CrossRef]

60. Poon, S.L.; McPherson, J.R.; Tan, P.; Teh, B.T.; Rozen, S.G. Mutation Signatures of Carcinogen Exposure: Genome-Wide Detection and New Opportunities for Cancer Prevention. Genome Med. 2014, 6, 24. [CrossRef]

61. Srinivas, N.; Malla, R.R.; Suresh Kumar, K.; Ram Sailesh, A. Chapter 15-Environmental Carcinogens and Their Impact on Female-Specific Cancers. In A Theranostic and Precision Medicine Approach for Female-Specific Cancers; Malla, R.R., Nagaraju, G.P., Eds.; Academic Press: Cambridge, MA, USA, 2021; pp. 249-262, ISBN 978-0-12-822009-2.

62. Williams, K.; Sobol, R.W. Mutation Research/Fundamental and Molecular Mechanisms of Mutagenesis: Special Issue: DNA Repair and Genetic Instability. Mutat. Res. 2013, 743, 53-66. [CrossRef]

63. Apás, A.L.; González, S.N.; Arena, M.E. Potential of Goat Probiotic to Bind Mutagens. Anaerobe 2014, 28, 8-12. [CrossRef]

64. Ahmadi, M.A.; Ebrahimi, M.T.; Mehrabian, S.; Tafvizi, F.; Bahrami, H.; Dameshghian, M. Antimutagenic and Anticancer Effects of Lactic Acid Bacteria Isolated from Tarhana through Ames Test and Phylogenetic Analysis by 16S RDNA. Nutr. Cancer 2014, 66, 1406-1413. [CrossRef]

65. Surono, I.S.; Pato, U.; Koesnandar, K.; Hosono, A. In Vivo Antimutagenicity of Dadih Probiotic Bacteria towards Trp-P1. Asian-Australas. J. Anim. Sci. 2009, 22, 119-123. [CrossRef]

66. Matar, C.; Nadathur, S.S.; Bakalinsky, A.T.; Goulet, J. Antimutagenic Effects of Milk Fermented by Lactobacillus Helveticus L89 and a Protease-Deficient Derivative. J. Dairy Sci. 1997, 80, 1965-1970. [CrossRef]

67. Pithva, S.P.; Dave, J.M.; Vyas, B.R.M. Binding of Acridine Orange by Probiotic Lactobacillus Rhamnosus Strains of Human Origin. Ann. Microbiol. 2015, 65, 1373-1379. [CrossRef]

68. Selection and Characterization of Probiotic Lactic Acid Bacteria with Heterocyclic Amine Binding and Nitrosamine Degradation Properties. J. Appl. Pharm. Sci. 2014, 4. [CrossRef]

69. Chalova, V.I.; Lingbeck, J.M.; Kwon, Y.M.; Ricke, S.C. Extracellular Antimutagenic Activities of Selected Probiotic Bifidobacterium and Lactobacillus Spp. as a Function of Growth Phase. J. Environ. Sci. Health B 2008, 43, 193-198. [CrossRef] [PubMed]

70. Sreekumar, O.; Hosono, A. The Antimutagenic Properties of a Polysaccharide Produced by Bifidobacterium Longum and Its Cultured Milk against Some Heterocyclic Amines. Can. J. Microbiol. 1998, 44, 1029-1036. [CrossRef]

71. Pei-Ren, L.; Roch-Chuiyu; Cheng-Chun, C.; Ya-Hui, T. Antimutagenic Activity of Several Probiotic Bifidobacteria against Benzo[a]Pyrene. J. Biosci. Bioeng. 2002, 94, 148-153. [CrossRef]

72. Hosoda, M.; Hashimoto, H.; Morita, H.; Chiba, M.; Hosono, A. Antimutagenicity of Milk Cultured with Lactic Acid Bacteria against N-Methyl-N'-Nitro-N-Nitrosoguanidine. J. Dairy Sci. 1992, 75, 976-981. [CrossRef]

73. Nadathur, S.R.; Gould, S.J.; Bakalinsky, A.T. Antimutagenicity of Fermented Milk. J. Dairy Sci. 1994, 77, 3287-3295. [CrossRef]

74. Lim, S.-M. Antimutagenicity Activity of the Putative Probiotic Strain Lactobacillus Paracasei Subsp. Tolerans JG22 Isolated from Pepper Leaves Jangajji. Food Sci. Biotechnol. 2014, 23, 141-150. [CrossRef]

75. Pool-Zobel, B.L.; Neudecker, C.; Domizlaff, I.; Ji, S.; Schillinger, U.; Rumney, C.; Moretti, M.; Vilarini, I.; Scassellati-Sforzolini, R.; Rowland, I. Lactobacillus- and Bifidobacterium-Mediated Antigenotoxicity in the Colon of Rats. Nutr. Cancer 1996, 26, 365-380. [CrossRef]

76. Park, H.-D.; Rhee, C.-H. Antimutagenic Activity of Lactobacillus Plantarum KLAB21 Isolated from Kimchi Korean Fermented Vegetables. Biotechnol. Lett. 2001, 23, 1583-1589. [CrossRef]

77. Hosoda, M.; Hashimoto, H.; Morita, H.; Chiba, M.; Hosono, A. Studies on Antimutagenic Effect of Milk Cultured with Lactic Acid Bacteria on the Trp-P2-Induced Mutagenicity to TA98 Strain of Salmonella Typhimurium. J. Dairy Res. 1992, 59, 543-549. [CrossRef]

78. Hosono, A.; Kashina, T.; Kada, T. Antimutagenic Properties of Lactic Acid-Cultured Milk on Chemical and Fecal Mutagens. J. Dairy Sci. 1986, 69, 2237-2242. [CrossRef]

79. Sah, B.N.P.; Vasiljevic, T.; McKechnie, S.; Donkor, O.N. Effect of Probiotics on Antioxidant and Antimutagenic Activities of Crude Peptide Extract from Yogurt. Food Chem. 2014, 156, 264-270. [CrossRef]

80. Raipulis, J.; Toma, M.M.; Semjonovs, P. The Effect of Probiotics on the Genotoxicity of Furazolidone. Int. J. Food Microbiol. 2005, 102, 343-347. [CrossRef] [PubMed]

81. Pithva, S.P.; Ambalam, P.S.; Ramoliya, J.M.; Dave, J.M.; Vyas, B.R.M. Antigenotoxic and Antimutagenic Activities of Probiotic Lactobacillus Rhamnosus Vc against N-Methyl-N'-Nitro-N-Nitrosoguanidine. Nutr. Cancer 2015, 67, 1142-1150. [CrossRef] [PubMed]

82. Stidl, R.; Sontag, G.; Koller, V.; Knasmüller, S. Binding of Heterocyclic Aromatic Amines by Lactic Acid Bacteria: Results of a Comprehensive Screening Trial. Mol. Nutr. Food Res. 2008, 52, 322-329. [CrossRef] [PubMed]

83. Ahmad, A.; Salik, S.; Yap, W.B.; Kofli, N.T.; Ghazali, A.R. Mutagenicity and Antimutagenic Activities of Lactic Acid Bacteria (LAB) Isolated from Fermented Durian (Tempoyak). J. Sains Kesihat. Malays. 2018, 16, 23-26. [CrossRef]

84. Rhee, C.-H.; Park, H.-D. Three Glycoproteins with Antimutagenic Activity Identified in Lactobacillus Plantarum KLAB21. Appl. Environ. Microbiol. 2001, 67, 3445-3449. [CrossRef]

85. Średnicka, P.; Juszczuk-Kubiak, E.; Wójcicki, M.; Akimowicz, M.; Roszko, M.Ł. Probiotics as a Biological Detoxification Tool of Food Chemical Contamination: A Review. Food Chem. Toxicol. Int. J. Publ. Br. Ind. Biol. Res. Assoc. 2021, 153, 112306. [CrossRef] [PubMed] 
86. Levine, A.J.; Puzio-Kuter, A.M. The Control of the Metabolic Switch in Cancers by Oncogenes and Tumor Suppressor Genes. Science 2010, 330, 1340-1344. [CrossRef] [PubMed]

87. Corcos, D. Unbalanced Replication as a Major Source of Genetic Instability in Cancer Cells. Am. J. Blood Res. 2012, 2, 160-169. [PubMed]

88. Patel, K.R.; Patel, H.D. P53: An Attractive Therapeutic Target for Cancer. Curr. Med. Chem. 2020, 27, 3706-3734. [CrossRef]

89. Sherr, C.J. Principles of Tumor Suppression. Cell 2004, 116, 235-246. [CrossRef]

90. Vivarelli, S.; Salemi, R.; Candido, S.; Falzone, L.; Santagati, M.; Stefani, S.; Torino, F.; Banna, G.L.; Tonini, G.; Libra, M. Gut Microbiota and Cancer: From Pathogenesis to Therapy. Cancers 2019, 11, 38. [CrossRef]

91. Sharma, M.; Shukla, G. Metabiotics: One Step Ahead of Probiotics; an Insight into Mechanisms Involved in Anticancerous Effect in Colorectal Cancer. Front. Microbiol. 2016, 7, 1940. [CrossRef]

92. Kanwal, R.; Gupta, K.; Gupta, S. Cancer Epigenetics: An Introduction. Methods Mol. Biol. 2015, 1238, 3-25. [CrossRef]

93. Sharma, M.; Shukla, G. Administration of Metabiotics Extracted From Probiotic Lactobacillus Rhamnosus MD 14 Inhibit Experimental Colorectal Carcinogenesis by Targeting Wnt/ $\beta$-Catenin Pathway. Front. Oncol. 2020, 10, 746. [CrossRef]

94. Sharaf, L.K.; Sharma, M.; Chandel, D.; Shukla, G. Prophylactic Intervention of Probiotics (L.Acidophilus, L.Rhamnosus GG) and Celecoxib Modulate Bax-Mediated Apoptosis in 1,2-Dimethylhydrazine-Induced Experimental Colon Carcinogenesis. BMC Cancer 2018, 18, 1111. [CrossRef]

95. Fahmy, C.A.; Gamal-Eldeen, A.M.; El-Hussieny, E.A.; Raafat, B.M.; Mehanna, N.S.; Talaat, R.M.; Shaaban, M.T. Bifidobacterium Longum Suppresses Murine Colorectal Cancer through the Modulation of OncomiRs and Tumor Suppressor MiRNAs. Nutr. Cancer 2019, 71, 688-700. [CrossRef]

96. Kumar, M.; Hemalatha, R.; Kumar, R.; Nagpal, R.; Devraj, J.P.; Verma, V.; Behare, P.; Mal, G.; Singh, B. Epigenetics, Probiotic Metabolites and Colon Cancer Prevention: An Overview of Progress, Opportunities and Challenges. Med. Epigenet. 2013, 1, 60-69. [CrossRef]

97. Paul, D. The Systemic Hallmarks of Cancer. J. Cancer Metastasis Treat. 2020, 6, 29. [CrossRef]

98. Brown, G. Oncogenes, Proto-Oncogenes, and Lineage Restriction of Cancer Stem Cells. Int. J. Mol. Sci. 2021, 22, 9667. [CrossRef]

99. Wang, C.; Zhang, J.; Yin, J.; Gan, Y.; Xu, S.; Gu, Y.; Huang, W. Alternative Approaches to Target Myc for Cancer Treatment. Signal Transduct. Target. Ther. 2021, 6, 1-14. [CrossRef] [PubMed]

100. Kontomanolis, E.N.; Koutras, A.; Syllaios, A.; Schizas, D.; Mastoraki, A.; Garmpis, N.; Diakosavvas, M.; Angelou, K.; Tsatsaris, G.; Pagkalos, A.; et al. Role of Oncogenes and Tumor-Suppressor Genes in Carcinogenesis: A Review. Anticancer Res. 2020, 40, 6009-6015. [CrossRef]

101. Azam, R.; Ghafouri-Fard, S.; Tabrizi, M.; Modarressi, M.-H.; Ebrahimzadeh-Vesal, R.; Daneshvar, M.; Mobasheri, M.B.; Motevaseli, E. Lactobacillus Acidophilus and Lactobacillus Crispatus Culture Supernatants Downregulate Expression of Cancer-Testis Genes in the MDA-MB-231 Cell Line. Asian Pac. J. Cancer Prev. APJCP 2014, 15, 4255-4259. [CrossRef] [PubMed]

102. Motevaseli, E.; Shirzad, M.; Akrami, S.M.; Mousavi, A.-S.; Mirsalehian, A.; Modarressi, M.H. Normal and Tumour Cervical Cells Respond Differently to Vaginal Lactobacilli, Independent of PH and Lactate. J. Med. Microbiol. 2013, 62, 1065-1072. [CrossRef]

103. Taherian-Esfahani, Z.; Abedin-Do, A.; Nouri, Z.; Mirfakhraie, R.; Ghafouri-Fard, S.; Motevaseli, E. Lactobacilli Differentially Modulate MTOR and Wnt/ $\beta$-Catenin Pathways in Different Cancer Cell Lines. Iran. J. Cancer Prev. 2016, 9, e5369. [CrossRef] [PubMed]

104. Hosseini, S.S.; Goudarzi, H.; Ghalavand, Z.; Hajikhani, B.; Rafeieiatani, Z.; Hakemi-Vala, M. Anti-Proliferative Effects of Cell Wall, Cytoplasmic Extract of Lactococcus Lactis and Nisin through down-Regulation of Cyclin D1 on SW480 Colorectal Cancer Cell Line. Iran. J. Microbiol. 2020, 12, 424-430. [CrossRef] [PubMed]

105. Kim, H.R.; Kim, H.; Jung, B.J.; You, G.E.; Jang, S.; Chung, D.K. Lipoteichoic Acid Isolated from Lactobacillus Plantarum Inhibits Melanogenesis in B16F10 Mouse Melanoma Cells. Mol. Cells 2015, 38, 163-170. [CrossRef]

106. Fares, J.; Fares, M.Y.; Khachfe, H.H.; Salhab, H.A.; Fares, Y. Molecular Principles of Metastasis: A Hallmark of Cancer Revisited. Signal Transduct. Target. Ther. 2020, 5, 1-17. [CrossRef] [PubMed]

107. Pachmayr, E.; Treese, C.; Stein, U. Underlying Mechanisms for Distant Metastasis-Molecular Biology. Visc. Med. 2017, 33, 11-20. [CrossRef]

108. Dillekås, H.; Rogers, M.S.; Straume, O. Are 90\% of Deaths from Cancer Caused by Metastases? Cancer Med. 2019, 8, 5574-5576. [CrossRef]

109. Ribatti, D.; Tamma, R.; Annese, T. Epithelial-Mesenchymal Transition in Cancer: A Historical Overview. Transl. Oncol. 2020, 13, 100773. [CrossRef] [PubMed]

110. Yang, J.; Antin, P.; Berx, G.; Blanpain, C.; Brabletz, T.; Bronner, M.; Campbell, K.; Cano, A.; Casanova, J.; Christofori, G.; et al. Guidelines and Definitions for Research on Epithelial-Mesenchymal Transition. Nat. Rev. Mol. Cell Biol. 2020, $21,341-352$. [CrossRef]

111. Hapach, L.A.; Mosier, J.A.; Wang, W.; Reinhart-King, C.A. Engineered Models to Parse Apart the Metastatic Cascade. NPJ Precis. Oncol. 2019, 3, 1-8. [CrossRef]

112. Steeg, P.S. Targeting Metastasis. Nat. Rev. Cancer 2016, 16, 201-218. [CrossRef]

113. Escamilla, J.; Lane, M.A.; Maitin, V. Probiotic Lactobacilli Decrease Invasion of Metastatic Human Colon Cancer Cells In Vitro. FASEB J. 2010, 24, 928.21. [CrossRef] 
114. Escamilla, J.; Lane, M.A.; Maitin, V. Cell-Free Supernatants from Probiotic Lactobacillus Casei and Lactobacillus Rhamnosus GG Decrease Colon Cancer Cell Invasion in Vitro. Nutr. Cancer 2012, 64, 871-878. [CrossRef] [PubMed]

115. Yue, Y.-C.; Yang, B.-Y.; Lu, J.; Zhang, S.-W.; Liu, L.; Nassar, K.; Xu, X.-X.; Pang, X.-Y.; Lv, J.-P. Metabolite Secretions of Lactobacillus Plantarum YYC-3 May Inhibit Colon Cancer Cell Metastasis by Suppressing the VEGF-MMP2/9 Signaling Pathway. Microb. Cell Factories 2020, 19, 213. [CrossRef] [PubMed]

116. Duffy, A.M.; Bouchier-Hayes, D.J.; Harmey, J.H. Vascular Endothelial Growth Factor (VEGF) and Its Role in Non-Endothelial Cells: Autocrine Signalling by VEGF; Landes Bioscience: Austin, TX, USA, 2013.

117. Quintero-Fabián, S.; Arreola, R.; Becerril-Villanueva, E.; Torres-Romero, J.C.; Arana-Argáez, V.; Lara-Riegos, J.; Ramírez-Camacho, M.A.; Alvarez-Sánchez, M.E. Role of Matrix Metalloproteinases in Angiogenesis and Cancer. Front. Oncol. 2019, 9, 1370. [CrossRef]

118. Braga, V. Spatial Integration of E-Cadherin Adhesion, Signalling and the Epithelial Cytoskeleton. Curr. Opin. Cell Biol. 2016, 42, 138-145. [CrossRef]

119. Li, X.; Wang, H.; Du, X.; Yu, W.; Jiang, J.; Geng, Y.; Guo, X.; Fan, X.; Ma, C. Lactobacilli Inhibit Cervical Cancer Cell Migration in Vitro and Reduce Tumor Burden in Vivo through Upregulation of E-Cadherin. Oncol. Rep. 2017, 38, 1561-1568. [CrossRef]

120. Chen, S.-M.; Hsu, L.-J.; Lee, H.-L.; Lin, C.-P.; Huang, S.-W.; Lai, C.J.-L.; Lin, C.-W.; Chen, W.-T.; Chen, Y.-J.; Lin, Y.-C.; et al. Lactobacillus Attenuate the Progression of Pancreatic Cancer Promoted by Porphyromonas Gingivalis in K-RasG12D Transgenic Mice. Cancers 2020, 12, 3522. [CrossRef] [PubMed]

121. Zamberi, N.R.; Abu, N.; Mohamed, N.E.; Nordin, N.; Keong, Y.S.; Beh, B.K.; Zakaria, Z.A.B.; Nik Abdul Rahman, N.M.A.; Alitheen, N.B. The Antimetastatic and Antiangiogenesis Effects of Kefir Water on Murine Breast Cancer Cells. Integr. Cancer Ther. 2016, 15, NP53-NP66. [CrossRef]

122. Ardito, F.; Giuliani, M.; Perrone, D.; Troiano, G.; Muzio, L.L. The Crucial Role of Protein Phosphorylation in Cell Signaling and Its Use as Targeted Therapy (Review). Int. J. Mol. Med. 2017, 40, 271-280. [CrossRef]

123. Kannaiyan, R.; Mahadevan, D. A Comprehensive Review of Protein Kinase Inhibitors for Cancer Therapy. Expert Rev. Anticancer Ther. 2018, 18, 1249-1270. [CrossRef]

124. Manning, G.; Whyte, D.B.; Martinez, R.; Hunter, T.; Sudarsanam, S. The Protein Kinase Complement of the Human Genome. Science 2002, 298, 1912-1934. [CrossRef]

125. Shi, Y. Serine/Threonine Phosphatases: Mechanism through Structure. Cell 2009, 139, 468-484. [CrossRef]

126. Hanahan, D.; Weinberg, R.A. Hallmarks of Cancer: The next Generation. Cell 2011, 144, 646-674. [CrossRef] [PubMed]

127. Bhullar, K.S.; Lagarón, N.O.; McGowan, E.M.; Parmar, I.; Jha, A.; Hubbard, B.P.; Rupasinghe, H.P.V. Kinase-Targeted Cancer Therapies: Progress, Challenges and Future Directions. Mol. Cancer 2018, 17, 48. [CrossRef] [PubMed]

128. Secombe, K.R.; Van Sebille, Y.Z.A.; Mayo, B.J.; Coller, J.K.; Gibson, R.J.; Bowen, J.M. Diarrhea Induced by Small Molecule Tyrosine Kinase Inhibitors Compared With Chemotherapy: Potential Role of the Microbiome. Integr. Cancer Ther. 2020, 19, 1534735420928493. [CrossRef]

129. Ianiro, G.; Rossi, E.; Thomas, A.M.; Schinzari, G.; Masucci, L.; Quaranta, G.; Settanni, C.R.; Lopetuso, L.R.; Armanini, F.; Blanco-Miguez, A.; et al. Faecal Microbiota Transplantation for the Treatment of Diarrhoea Induced by Tyrosine-Kinase Inhibitors in Patients with Metastatic Renal Cell Carcinoma. Nat. Commun. 2020, 11, 1-6. [CrossRef]

130. Seth, A.; Yan, F.; Polk, D.B.; Rao, R.K. Probiotics Ameliorate the Hydrogen Peroxide-Induced Epithelial Barrier Disruption by a PKC- and MAP Kinase-Dependent Mechanism. Am. J. Physiol. Gastrointest. Liver Physiol. 2008, 294, G1060-G1069. [CrossRef] [PubMed]

131. Şener, D.; Bulut, H.N.; Güneș Bayir, A. Probiotics and Relationship Between Probiotics and Cancer Types. Bezmialem Sci. 2021, 9 , 490-497. [CrossRef]

132. Han, K.J.; Lee, N.-K.; Park, H.; Paik, H.-D. Anticancer and Anti-Inflammatory Activity of Probiotic Lactococcus Lactis NK34. J. Microbiol. Biotechnol. 2015, 25, 1697-1701. [CrossRef]

133. Ayyanna, R.; Ankaiah, D.; Arul, V. Anti-Inflammatory and Antioxidant Properties of Probiotic Bacterium Lactobacillus Mucosae AN1 and Lactobacillus Fermentum SNR1 in Wistar Albino Rats. Front. Microbiol. 2018, 9, 3063. [CrossRef]

134. Chooruk, A.; Piwat, S.; Teanpaisan, R. Antioxidant Activity of Various Oral Lactobacillus Strains. J. Appl. Microbiol. 2017, 123, 271-279. [CrossRef]

135. Yang, S.J.; Kim, K.-T.; Kim, T.Y.; Paik, H.-D. Probiotic Properties and Antioxidant Activities of Pediococcus Pentosaceus SC28 and Levilactobacillus Brevis KU15151 in Fermented Black Gamju. Foods Basel Switz. 2020, 9, 1154. [CrossRef]

136. Pompei, A.; Cordisco, L.; Amaretti, A.; Zanoni, S.; Matteuzzi, D.; Rossi, M. Folate Production by Bifidobacteria as a Potential Probiotic Property. Appl. Environ. Microbiol. 2007, 73, 179-185. [CrossRef] [PubMed]

137. Olgun, A. "Metformin-Resistant" Folic Acid Producing Probiotics or Folic Acid against Metformin's Adverse Effects like Diarrhea. Med. Hypotheses 2017, 106, 33-34. [CrossRef] [PubMed]

138. Malvisi, M.; Stuknytė, M.; Magro, G.; Minozzi, G.; Giardini, A.; De Noni, I.; Piccinini, R. Antibacterial Activity and Immunomodulatory Effects on a Bovine Mammary Epithelial Cell Line Exerted by Nisin A-Producing Lactococcus Lactis Strains. J. Dairy Sci. 2016, 99, 2288-2296. [CrossRef] [PubMed] 
139. Indira, M.; Venkateswarulu, T.C.; Vidya Prabhakar, K.; Abraham Peele, K.; Krupanidhi, S. Isolation and Characterization of Bacteriocin Producing Enterococcus Casseliflavus and Its Antagonistic Effect on Pseudomonas Aeruginosa. Karbala Int. J. Mod. Sci. 2018, 4, 361-368. [CrossRef]

140. Al-Madboly, L.A.; El-Deeb, N.M.; Kabbash, A.; Nael, M.A.; Kenawy, A.M.; Ragab, A.E. Purification, Characterization, Identification, and Anticancer Activity of a Circular Bacteriocin From Enterococcus Thailandicus. Front. Bioeng. Biotechnol. $2020,8,450$. [CrossRef] [PubMed]

141. Baindara, P.; Gautam, A.; Raghava, G.P.S.; Korpole, S. Anticancer Properties of a Defensin like Class IId Bacteriocin Laterosporulin10. Sci. Rep. 2017, 7, 46541. [CrossRef]

142. Negash, A.W.; Tsehai, B.A. Current Applications of Bacteriocin. Int. J. Microbiol. 2020, 2020, e4374891. [CrossRef]

143. Yang, S.-C.; Lin, C.-H.; Sung, C.T.; Fang, J.-Y. Antibacterial Activities of Bacteriocins: Application in Foods and Pharmaceuticals. Front. Microbiol. 2014, 5, 241. [CrossRef]

144. Nami, Y.; Abdullah, N.; Haghshenas, B.; Radiah, D.; Rosli, R.; Khosroushahi, A.Y. Assessment of Probiotic Potential and Anticancer Activity of Newly Isolated Vaginal Bacterium Lactobacillus Plantarum 5BL. Microbiol. Immunol. 2014, 58, 492-502. [CrossRef]

145. Rupasinghe, H.P.V.; Parmar, I.; Neir, S.V. Biotransformation of Cranberry Proanthocyanidins to Probiotic Metabolites by Lactobacillus Rhamnosus Enhances Their Anticancer Activity in HepG2 Cells In Vitro. Oxid. Med. Cell. Longev. 2019, 2019, e4750795. [CrossRef]

146. Karpiński, T.M.; Adamczak, A. Anticancer Activity of Bacterial Proteins and Peptides. Pharmaceutics 2018, 10, 54. [CrossRef]

147. Kaur, S.; Kaur, S. Bacteriocins as Potential Anticancer Agents. Front. Pharmacol. 2015, 6, 272. [CrossRef]

148. Lorent, J.H.; Levental, K.R.; Ganesan, L.; Rivera-Longsworth, G.; Sezgin, E.; Doktorova, M.; Lyman, E.; Levental, I. Plasma Membranes Are Asymmetric in Lipid Unsaturation, Packing and Protein Shape. Nat. Chem. Biol. 2020, 16, 644-652. [CrossRef] [PubMed]

149. Fadeel, B.; Xue, D. The Ins and Outs of Phospholipid Asymmetry in the Plasma Membrane: Roles in Health and Disease. Crit. Rev. Biochem. Mol. Biol. 2009, 44, 264-277. [CrossRef]

150. Cho, G.; Lee, E.; Kim, J. Structural Insights into Phosphatidylethanolamine Formation in Bacterial Membrane Biogenesis. Sci. Rep. 2021, 11, 5785. [CrossRef] [PubMed]

151. Oelkrug, C.; Hartke, M.; Schubert, A. Mode of Action of Anticancer Peptides (ACPs) from Amphibian Origin. Anticancer Res. 2015, 35, 635-643. [PubMed]

152. Piotrowska, U.; Sobczak, M.; Oledzka, E. Current State of a Dual Behaviour of Antimicrobial Peptides-Therapeutic Agents and Promising Delivery Vectors. Chem. Biol. Drug Des. 2017, 90, 1079-1093. [CrossRef]

153. He, J.-F.; Jin, D.-X.; Luo, X.-G.; Zhang, T.-C. LHH1, a Novel Antimicrobial Peptide with Anti-Cancer Cell Activity Identified from Lactobacillus Casei HZ1. AMB Express 2020, 10, 204. [CrossRef]

154. Varas, M.A.; Muñoz-Montecinos, C.; Kallens, V.; Simon, V.; Allende, M.L.; Marcoleta, A.E.; Lagos, R. Exploiting Zebrafish Xenografts for Testing the in Vivo Antitumorigenic Activity of Microcin E492 Against Human Colorectal Cancer Cells. Front. Microbiol. 2020, 11, 405. [CrossRef]

155. Meade, E.; Slattery, M.A.; Garvey, M. Bacteriocins, Potent Antimicrobial Peptides and the Fight against Multi Drug Resistant Species: Resistance Is Futile? Antibiotics 2020, 9, 32. [CrossRef]

156. Pinilla, C.M.B.; Lopes, N.A.; Brandelli, A. Lipid-Based Nanostructures for the Delivery of Natural Antimicrobials. Molecules 2021, 26, 3587. [CrossRef]

157. Fahim, H.A.; Khairalla, A.S.; El-Gendy, A.O. Nanotechnology: A Valuable Strategy to Improve Bacteriocin Formulations. Front. Microbiol. 2016, 7, 1385. [CrossRef]

158. Amer, S.A.; Abushady, H.M.; Refay, R.M.; Mailam, M.A. Enhancement of the Antibacterial Potential of Plantaricin by Incorporation into Silver Nanoparticles. J. Genet. Eng. Biotechnol. 2021, 19, 13. [CrossRef] [PubMed]

159. van Staden, A.D.; Brand, A.M.; Dicks, L.M.T. Nisin F-Loaded Brushite Bone Cement Prevented the Growth of Staphylococcus Aureus in Vivo. J. Appl. Microbiol. 2012, 112, 831-840. [CrossRef]

160. Sundara Rajan, S.; Cavera, V.L.; Zhang, X.; Singh, Y.; Chikindas, M.L.; Sinko, P.J. Polyethylene Glycol-Based Hydrogels for Controlled Release of the Antimicrobial Subtilosin for Prophylaxis of Bacterial Vaginosis. Antimicrob. Agents Chemother. 2014, 58, 2747-2753. [CrossRef]

161. Bonifait, L.; Chandad, F.; Grenier, D. Probiotics for Oral Health: Myth or Reality? J. Can. Dent. Assoc. 2009, 75, 585-590. [PubMed]

162. Gillor, O.; Etzion, A.; Riley, M.A. The Dual Role of Bacteriocins as Anti- and Probiotics. Appl. Microbiol. Biotechnol. 2008, 81, 591-606. [CrossRef]

163. Cerqueira, L.; Oliveira, J.A.; Nicolau, A.; Azevedo, N.F.; Vieira, M.J. Biofilm Formation with Mixed Cultures of Pseudomonas Aeruginosa/Escherichia Coli on Silicone Using Artificial Urine to Mimic Urinary Catheters. Biofouling 2013, 29, 829-840. [CrossRef]

164. Laine, C.; Horton, R.; DeAngelis, C.D.; Drazen, J.M.; Frizelle, F.A.; Godlee, F.; Haug, C.; Hébert, P.C.; Kotzin, S.; Marusic, A.; et al. Clinical Trial Registration-Looking Back and Moving Ahead. N. Engl. J. Med. 2007, 356, 2734-2736. [CrossRef] [PubMed] 
165. Degnan, F.H. Clinical Studies Involving Probiotics: When FDA's Investigational New Drug Rubric Applies-and When It May Not. Gut Microbes 2012, 3, 485-489. [CrossRef] [PubMed]

166. Dronkers, T.M.G.; Ouwehand, A.C.; Rijkers, G.T. Global Analysis of Clinical Trials with Probiotics. Heliyon 2020,6 , e04467. [CrossRef]

167. Jungersen, M.; Wind, A.; Johansen, E.; Christensen, J.E.; Stuer-Lauridsen, B.; Eskesen, D. The Science behind the Probiotic Strain Bifidobacterium Animalis Subsp. Lactis BB-12 ${ }^{\circledR}$. Microorganisms 2014, 2, 92-110. [CrossRef] [PubMed]

168. Singh, D.; Khan, M.A.; Siddique, H.R. Therapeutic Implications of Probiotics in Microbiota Dysbiosis: A Special Reference to the Liver and Oral Cancers. Life Sci. 2021, 285, 120008. [CrossRef] [PubMed] 